\title{
Hydrogeochemical delineation of groundwater fitness for drinking and agricultural utilities in Thiruvallur district, South India
}

\author{
Subramani Senthilkumar ${ }^{1}$ • Balu Gowtham ${ }^{2} \cdot$ Krishnaraj Srinivasamoorthy $^{1} \cdot$ Selvaraj Gopinath ${ }^{3}$
}

Received: 10 February 2020 / Accepted: 16 January 2021 / Published online: 15 March 2021

(C) The Author(s) 2021

\begin{abstract}
Appraisal of groundwater fitness to drinking, agricultural, and domestic purposes was attempted within the Thiruvallur district of South India since groundwater is the significant sources for the above utilities. Groundwater samples collected from a sum of 110 locations have to be analyzed for major concentrations of which higher values of total dissolved solids (TDS), chloride $\left(\mathrm{Cl}^{-}\right)$, and sodium $\left(\mathrm{Na}^{+}\right)$ions were noted during pre-monsoon (PRM) specifically besides the east along with the southeastern part of the study region and higher calcium $\left(\mathrm{Ca}^{2+}\right)$ and nitrate $\left(\mathrm{NO}_{3}{ }^{-}\right)$values disseminated besides the central and eastern parts of the study region during the post-monsoon (POM) season. Suitability of water quality depends upon total dissolved solids; Water Quality Index (WQI) suggests $70 \%$ and $62 \%$ of the study area representing hard and sedimentary formations are appropriate for consumption utilities. Irrigation aptness of water for utility suggests the majority of study area is suitable in view of electrical conductance, sodium adsorption ratio, USSL plot, Na\%, Wilcox's plot, Kelly's ratio, and Doneen's plot. Dominant hydrochemical facies were observed to be $\mathrm{Na}-\mathrm{Cl}$, mixed $\mathrm{Ca}-\mathrm{Mg}-\mathrm{Cl}$, and $\mathrm{Ca}-\mathrm{HCO}_{3}$, and parameters like $\mathrm{Na}^{+}, \mathrm{Ca}^{2+}, \mathrm{HCO}_{3}{ }^{-}$, $\mathrm{Cl}^{-}$, and $\mathrm{NO}_{3}{ }^{-}$ions have been observed to be higher in the central region next to the east and may be appropriate to influence geogenic, anthropogenic, and seawater encroachment.
\end{abstract}

Keywords Coastal groundwater $\cdot$ Hydrochemical facies $\cdot$ Wilcox diagram $\cdot$ Encroachment

\section{Introduction}

Groundwater forms the main source for drinking, household, industrial, and agricultural convenience in coastal regions of numerous countries. India is covered by $2.20 \%$ of global land and $4.0 \%$ of global water reserves, with $16 \%$ of the world's population. Due to increasing human utilities for household, farming, and industrialized utilities, the pressure on good water resources has drastically increased (Ramakrishnaiah et al. 2009).

This article is part of the Topical Collection on Recent advanced techniques in water resources management.

Subramani Senthilkumar siva.senthil.geo@gmail.com

1 Department of Earth Sciences, Pondicherry University, Puducherry, India

2 Department of Geology, Presidency College (Autonomous), Chennai, India

3 Instituto de Geofísica, UNAM Ciudad Universitaria, Mexico DF, Mexico
The groundwater eminence is subjective in litho-units, land use pattern, and anthropogenic activities (Srinivasamoorthy et al. 2011 and 2018; Saravanan et al. 2016; Senthilkumar et al. 2017, and Gopinath et al. 2018). Overexploitation of water and intense urbanization process with lack of water management activities has led to deteriorating water quality. As a result, water management and their quality are required in rising countries like India. In this country, severe irrigation behaviors have improved the need for groundwater wealth. Hydrogeochemical investigations provide a better understanding of hydrologic conditions and their usefulness in any region.

The process of interacting with aquifer material next to the flow paths within the subsurface is the contribution to the groundwater substance concentration (Srinivasamoorthy et al. 2008 and 2018; Senthilkumar et al. 2014a; Gopinath et al. 2017 and 2019; Prakash et al. 2018). Now, awareness is needed to understand the natural concentration of many ions and metals in water to regulate and discriminate geogenic and anthropogenic sources influencing the quality of groundwater within the aquifer. Many ions naturally occurring in drinking water have a significant impact on human health through deficiency or excessive intake (Frengstad et al. 2001). 
Concurrently, the factors to influence the chemical value of groundwater are lithology, soil type, parent rock character, composition of recharge water into the aquifer, and the duration of water being held in the aquifer material (Giridharan et al. 2008; Atikul Islam et al. 2016). Therefore, it is important to understand groundwater quality for its suitability for drinking and agricultural uses (Subramani et al. 2005; Chidambaram et al. 2011; Ramesh and Elango 2011; Krishnakumar et al. 2013; Senthilkumar et al. 2014a; Narsimha 2018; Jain and Vaid 2018). Appraising of water quality by water quality indices (WQIs) which integrates water quality data to mark has also been tried by many worldwide investigators (Nazeer et al. 2014; He et al. 2018; Khadse et al. 2016; Li et al. 2018a, 2018b; Wu et al. 2017; Akakuru and Akudinobi 2018; Gopinath et al. 2019).

The aim of the present study is to delimit the quality of ground water in Thiruvallur district and areas where groundwater is suitable or unsuitable for drinking and irrigation purposes. Thiruvallur district faces acute water shortage due to large usage of groundwater for agricultural, industrialized, and urbanization applications. A total utility of groundwater in this district for all purposes is about 1058.46 million cubic meters (CGWB 2007). Groundwater is being pumped to Chennai city for the last few decades for drinking water supplies, which have created a large decrease in water level (Senthilkumar et al. 2019). The factors influencing groundwater quality in this area are not restricted to rock water interaction, groundwater flow congestion of aquifer and excess groundwater withdrawal, use of chemical fertilizers, and municipal, manufacturing, and farming activities. The study area is enclose by surface water bodies like Poondy reservoir on the central portion of the study region and Puzhal, Cholavaram tanks in the eastern component of this area for agricultural activities (CGWB 2007), but due to their tendency to receive water only during monsoon, people have been urged to rely on groundwater potential for their everyday activities. At the same time, this area is very important, and potential aquifers provide water to all industries and domestic needs of the emerging Chennai city. The local level evaluation of groundwater suitability for drinking and irrigation utilities has been studied by Parimala renganayaki and Elango (2013), Brindha et al. (2013), and Krishna Kumar et al. (2017) in this study area. Senthilkumar et al. (2017b) have identified available groundwater potential zones in the sedimentary terrain of this study area using electrical sounding technique. The present study would be helpful to modify pumping schemes with more reasonable pumping hours and more suitable recharge methods to improve and sustain the groundwater quality for long-term planning and management to ensure saline-free water supply to future residents for sustainable utility of groundwater in this region. Therefore, the present study attempts to isolate groundwater suitability for drinking and agricultural purposes in Thiruvallur district of South India.

\section{Study area}

Thiruvallur district is placed north of Tamil Nadu state in India between northern latitude $12^{\circ} 57^{\prime} 32^{\prime \prime}$ and $13^{\circ} 33^{\prime} 0^{\prime \prime}$ and eastern longitude $79^{\circ} 17^{\prime} 32^{\prime \prime}$ and $80^{\circ} 20^{\prime} 15^{\prime \prime}$ according to the survey of Indian Toposheet No 57O/7, 8, 11, 12, 15 and $16,66 \mathrm{C} / 2,3,4,7$ and 8 , with an aerial extent of 3524.77 sq. $\mathrm{km}$ (Fig. 1). This area is bordered on the north by Andhra Pradesh, on the west by Vellore district, in the east by the Bay of Bengal, and in the south by Chennai and Kancheepuram districts. This area experiences tropical climatic condition with an annual mean least and most temperature of about $24.3^{\circ} \mathrm{C}$ and $32.9^{\circ} \mathrm{C}$ correspondingly. The mean yearly rainfall of the study area is $1104 \mathrm{~mm}$, out of which $52 \%$ of the precipitation is received during the northeast monsoon (October to December) and 41\% contributed from southwest monsoon experienced during July to September (Krishna Kumar et al. 2017). For hard rock aquifer, the water level is $5.5 \mathrm{~m}$ (bgl) during pre-monsoon and $1.5 \mathrm{~m}$ in post-monsoon time, and at the same time, sedimentary aquifer is $4 \mathrm{~m} \mathrm{(bgl)}$ and $0.5 \mathrm{~m}$ (bgl) for pre- and post-monsoon seasons. These water level variations indicated that the rainfall well is influenced to rise about $3-4 \mathrm{~m}$. The district traces rivers such as Araniyar, Koratalayar, Koum, Nagri, and Nandi, which flow in the eastern parts of the study area as well as west to east flowing directions. Among the rivers, Araniyar and Korattalayar are strongly influenced by backwater and tidal activities from the Bay of Bengal (Senthilkumar et al. 2019). The drainage pattern is dendritic, and all rivers are ephemeral in nature and have significant flows during the rainy season. The groundwater flow pattern is generally running from north to southward in the western part, and it turns from west to eastward direction in the eastern region.

The important geological units (Fig. 1) noted in the study area are confined to upper Gondwana formations with essential litho-units encompassing sand, coastal alluvium, silt, clay, sandstone, and conglomerate noted along the eastern and central parts of the study region (GSI 2005). In the western part, such litho-units representing Archean formations like granite gneiss, epidotehornblende gneiss, and charnockites are exposed. Geomorphologic features (Fig. 2) like alluvial plain is noted beside the central parts, coastal plain observed by the side of the eastern parts, and denudational hills and pediments distributed in the western part; flood plain and sedimentary high land represent a central segment of this study region. Groundwater into Archaean formations mainly occurs in weathered, fissured, and fractured portions of hard rock, and in recent alluviums, groundwater occurs in unconfined to semi-confined conditions (CGWB 2007). The major land use pattern of this area is followed by irrigation area, forest cover, wasteland, water bodies, and built-up land (Senthilkumar et al. 2017). Dolerite 

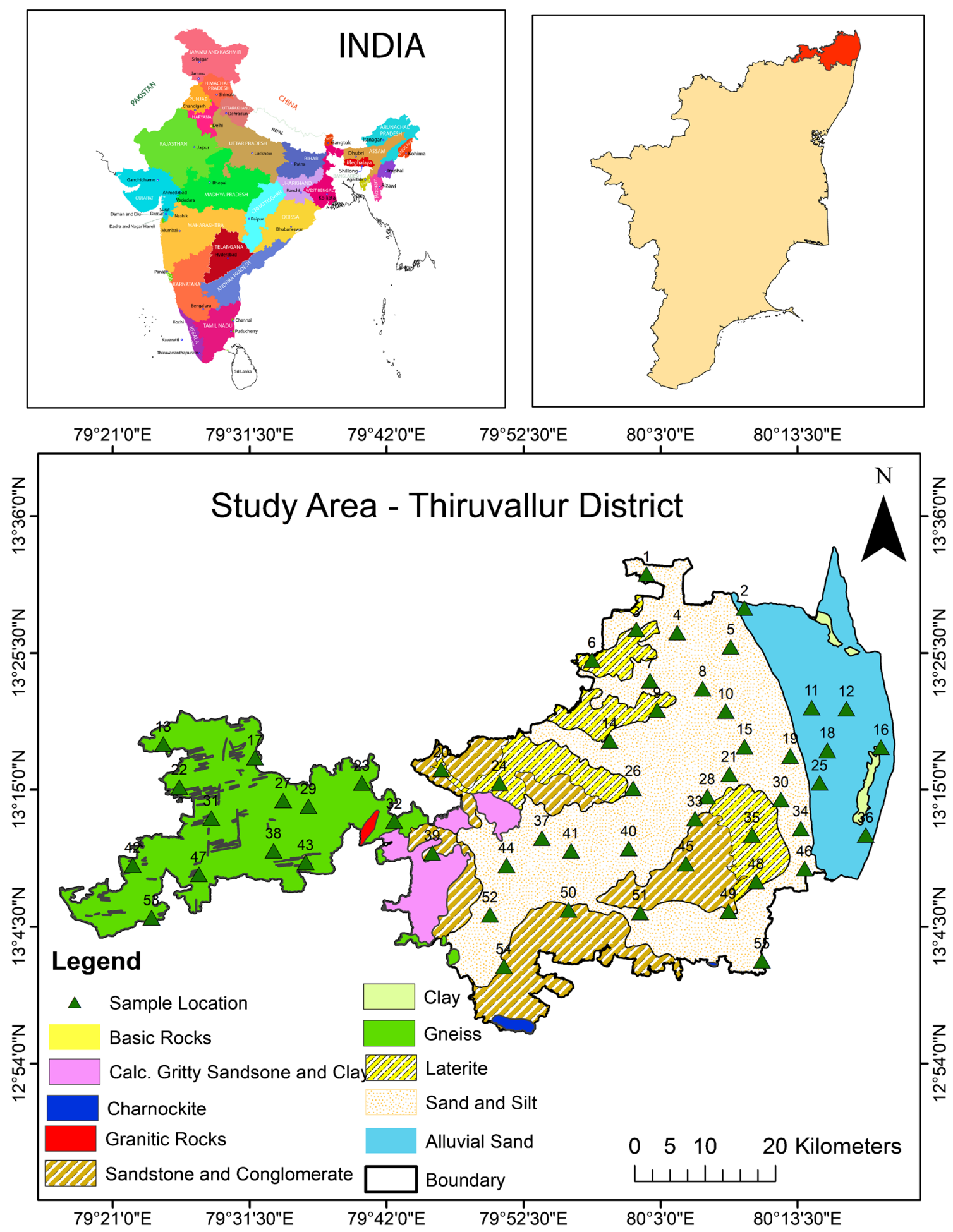

Fig. 1 Location and geology map

dyke, lineaments, fracture, and fissures are major geological structures are present in the western part of the study area (GSI 2005). The width of the unconfined aquifer in the rock region varies from 2 to $12 \mathrm{~m}$, and the average thickness of alluvium formation is $15 \mathrm{~m}$ in the study area. The yield of dug wells in the hard rock aquifer was 100 to
$500 \mathrm{lpm}$ and that in sedimentary bore wells ranges between 20 and $400 \mathrm{lpm}$. Transmissivity of the hard rock formation ranges from 14 to $750 \mathrm{~m}^{2} /$ day and in alluvium formation between 40 and $625 \mathrm{~m}^{2} /$ day. Specific yield of the study area in the hard rock formation varies from 0.092 to 0.000057 and sedimentary formations between 
Fig. 2 Geomorphology of the study area

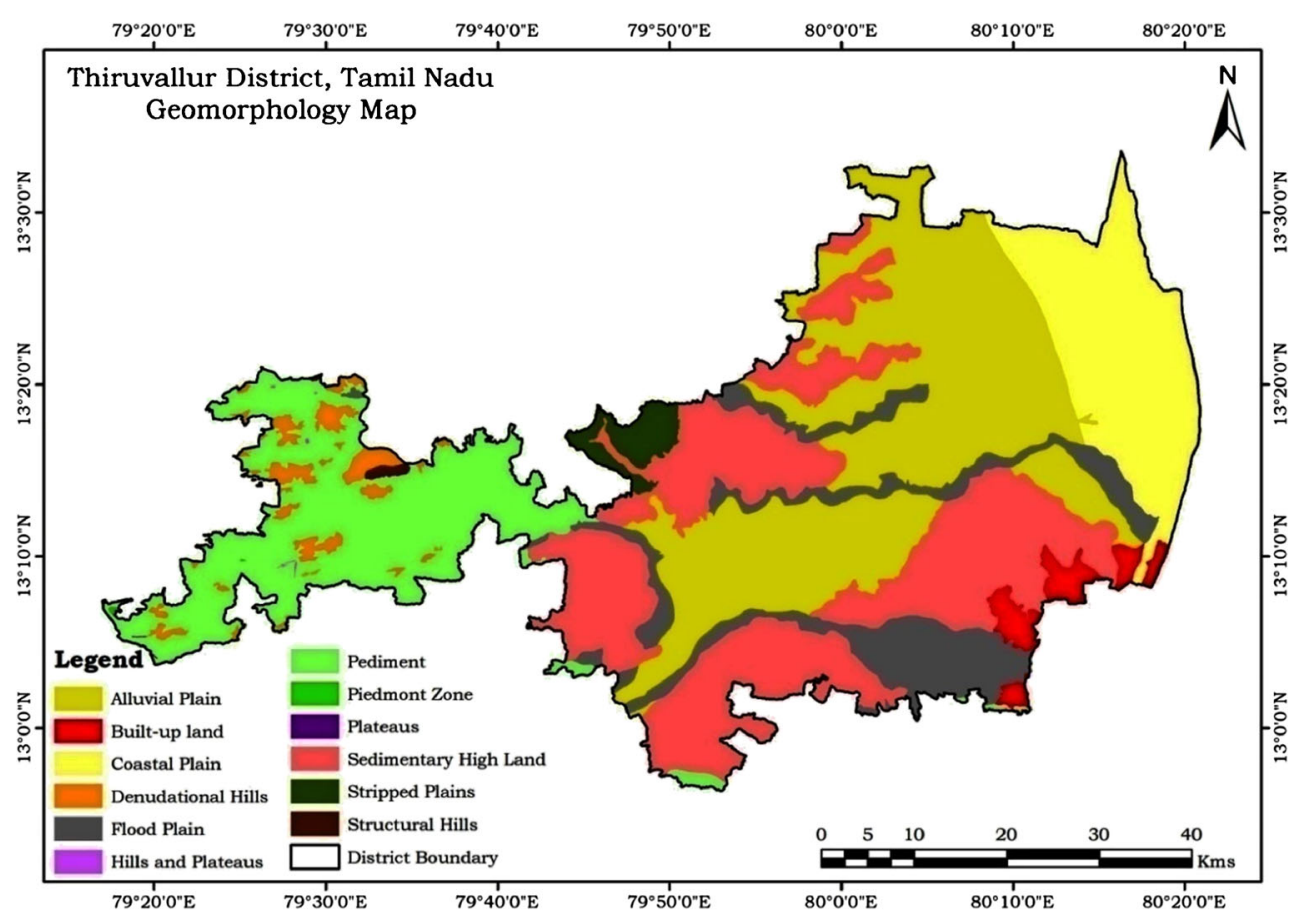

0.2 and 0.0001 (CGWB 2007). The tanks are major water catchment areas that are mostly rain fed tanks withholding water during the monsoon seasons, and in non-monsoonal periods, the tanks are dry.

\section{Material and methods}

Fifty-five groundwater samples were collected from representatives dug wells and bore wells for the period of June 2014 (pre-monsoon) and January 2015 (post-monsoon). From 55, 13 samples were collected from gneiss and charnockite formations along the western region, and the remaining 42 samples were collected from sedimentary formations limited to the central and eastern portions of the study area. Field measurements like electrical conductivity (EC) and hydrogen ion concentration $(\mathrm{pH})$ were measured using Systronics Water Quality Analyzer-371 at the time of sample collection. Each sample was collected in 1-1 capacity of clean polyethylene bottles, after pumping the sampled wells for $5 \mathrm{~min}$, and all the samples are filtered by $0.45 \mu$ Millipore paper to analyze major ion chemistry using standard procedures (APHA 2012). Volumetric titration methods were used to analyze calcium $\left(\mathrm{Ca}^{2+}\right)$, magnesium $\left(\mathrm{Mg}^{2+}\right)$ with $0.05 \mathrm{~N}$ EDTA solution, and carbonate $\left(\mathrm{CO}_{3}{ }^{2-}\right)$; bicarbonate $\left(\mathrm{HCO}^{3-}\right)$ was estimated by titration with $0.01 \mathrm{~N} \mathrm{H}_{2} \mathrm{SO}_{4}$ standard solution. Chloride $\left(\mathrm{Cl}^{-}\right)$was determined by titration with $0.02 \mathrm{~N} \mathrm{AgNO}_{3}$ solution. The flame photometer (ELICO CL 354) was used for measuring sodium $\left(\mathrm{Na}^{+}\right)$and potassium $\left(\mathrm{K}^{+}\right)$. Spectrophotometer ELICO SL 164 was used for measuring the sulfate $\left(\mathrm{SO}_{4}{ }^{2-}\right)$ and nitrate $\left(\mathrm{NO}_{3}{ }^{-}\right)$concentrations. The analytical error percentage of chemical analysis of \pm 5 was confirmed by ionic error balance. Parameters like $\mathrm{Na} \%$, sodium adsorption ratio (SAR), residual sodium carbonate (RSC), Permeability Index (PI), Kelly's ratio (KR) have been calculated using the following equations:

$$
\begin{gathered}
\mathrm{Na}^{+} \%=\frac{\left(\mathrm{Na}^{+}+\mathrm{K}^{+}\right) * 100}{\left(\mathrm{Ca}^{2+}+\mathrm{Mg}^{2+}+\mathrm{Na}^{+}+\mathrm{K}^{+}\right)} \mathrm{meq} / \mathrm{l} \\
\mathrm{SAR}=\frac{\mathrm{Na}^{+}}{\sqrt{\frac{\mathrm{Ca}^{2+}+\mathrm{Mg}^{2+}}{2}}} \\
\mathrm{RSC}=\left(\mathrm{CO}_{3}^{2-}+\mathrm{HCO}_{3}^{-}\right)-\left(\mathrm{Ca}^{2+}+\mathrm{Mg}^{2+}\right) \mathrm{meq} / 1 \\
\mathrm{PI}=\frac{\left(\mathrm{Na}^{+}+\sqrt{\mathrm{HCO}_{3}}\right) * 100}{\left(\mathrm{Na}^{+}+\mathrm{Mg}^{2+}+\mathrm{Ca}^{2+}\right)} \text { meq } / 1 \\
\text { Kelly's ratio }=\frac{\mathrm{Na}}{\mathrm{Ca}+\mathrm{Mg}} \mathrm{meq} / \mathrm{l}
\end{gathered}
$$

\section{Result and discussion}

The statistics of physicochemical parameters like electrical conductivity, $\mathrm{pH}$, and total dissolved solids and major elements $\mathrm{Na}^{+}, \mathrm{K}^{+}, \mathrm{Ca}^{2+}, \mathrm{Mg}^{2+}, \mathrm{Cl}^{-}, \mathrm{HCO}_{3}{ }^{-}, \mathrm{CO}_{3}{ }^{2-}, \mathrm{SO}_{4}{ }^{2-}$, $\mathrm{NO}_{3}{ }^{-}$) in pre-monsoon (PRM) and post-monsoon (POM) are accessible in Table 1 in view of varying litho-units. Meanwhile, $\mathrm{pH}$ is the most significant marker of its quality and prohibited by the sum of dissolved $\mathrm{CO}_{2}$, bicarbonate, and carbonate (Ghandour et al. 1985). The $\mathrm{pH}$ ranges from 6.8 to 
Table 1 Minimum, maximum, and average for the chemical composition of groundwater (in mg/l) except EC (in $\mu \mathrm{S} / \mathrm{cm}$ ) and $\mathrm{pH}$

\begin{tabular}{|c|c|c|c|c|c|c|c|c|c|c|c|c|}
\hline \multicolumn{7}{|c|}{ Hard rock formation } & \multicolumn{6}{|c|}{ Sedimentary formation } \\
\hline \multirow[t]{2}{*}{ Ions } & \multicolumn{3}{|l|}{ PRM } & \multicolumn{3}{|l|}{ POM } & \multicolumn{3}{|c|}{ PRM } & \multicolumn{3}{|l|}{ POM } \\
\hline & Min & Max & Ave & Min & Max & Ave & Min & Max & Ave & Min & Max & Ave \\
\hline $\mathrm{pH}$ & 6.9 & 8.1 & 7.5 & 7.1 & 8.0 & 7.5 & 6.9 & 8.1 & 7.5 & 6.88 & 8.1 & 7.5 \\
\hline $\mathrm{EC}$ & 520 & 2346 & 1406 & 500 & 2384 & 1345 & 219 & 5870 & 1387 & 150 & 4930 & 1330 \\
\hline TDS & 333 & 1501 & 900 & 320 & 1526 & 861 & 140 & 3757 & 888 & 96 & 3155 & 851 \\
\hline $\mathrm{Ca}$ & 27 & 118 & 74 & 31 & 146 & 82 & 11 & 306 & 69 & 17 & 600 & 82 \\
\hline $\mathrm{Mg}$ & 19 & 88 & 40 & 17 & 88 & 35 & 7 & 252 & 37 & 6 & 116 & 29 \\
\hline $\mathrm{Na}$ & 27 & 164 & 113 & 57 & 173 & 117 & 6 & 382 & 111 & 8 & 259 & 103 \\
\hline $\mathrm{K}$ & 12 & 70 & 48 & 24 & 74 & 50 & 2 & 164 & 47 & 3 & 111 & 44 \\
\hline $\mathrm{Cl}$ & 25 & 360 & 226 & 60 & 479 & 224 & 18 & 1702 & 241 & 18 & 1453 & 231 \\
\hline $\mathrm{HCO}_{3}$ & 24 & 451 & 300 & 264 & 641 & 368 & 10 & 695 & 250 & 55 & 384 & 234 \\
\hline $\mathrm{SO}_{4}$ & 23 & 178 & 84 & 4 & 178 & 79 & 12 & 422 & 96 & 3 & 384 & 95 \\
\hline $\mathrm{NO}_{3}$ & 0 & 89 & 27 & 10 & 70 & 30 & 0 & 111 & 23 & 4 & 199 & 28 \\
\hline $\mathrm{TH}$ & 154 & 541 & 345 & 176 & 726 & 348 & 60 & 1798 & 322 & 70 & 1750 & 329 \\
\hline
\end{tabular}

8.1 with mean of 7.5 irrespective of seasons and litho units. $\mathrm{pH}$, irrespective of seasons and terrain, represents alkaline in nature because of bicarbonate from dissolved carbonate (Nagarajan et al. 2010). The value of $\mathrm{pH}$ in the study samples of drinking water is below the permissible limit as prescribed by BIS (2003) and WHO (2011). The electrical conductivity for groundwater samples during PRM varies from 520.0 to $2346.0 \mu \mathrm{S} / \mathrm{cm}$ with a mean value of $1406.0 \mu \mathrm{S} / \mathrm{cm}$ in hard rock samples and 219.0 to $5870.0 \mu \mathrm{S} / \mathrm{cm}$ with an average value of 1387.0 in sedimentary formations. For the duration of POM, values range from 500.0 to $2384.0 \mu \mathrm{S} / \mathrm{cm}$ with an average of $1345.0 \mu \mathrm{S} / \mathrm{cm}$ in hard rock; in sedimentary terrain, the values vary from 150.0 to $4930.0 \mu \mathrm{S} / \mathrm{cm}$ with a mean value of $1330.0 \mu \mathrm{S} / \mathrm{cm}$. Higher electrical conductivity rate occurs in sample no.18 at the eastern part of the study region encompassing sedimentary terrain. Higher electrical conductivity $(5870 \mu \mathrm{S} / \mathrm{cm})$ observed in sedimentary aquifer during PRM might be due to seawater encroachment (Senthilkumar et al. 2019; Gopinath et al. 2019). Total dissolved solids in hard rock aquifers ranges between 333.0 and $1501.0 \mathrm{mg} / \mathrm{L}$ with a mean value of $900.0 \mathrm{mg} / \mathrm{l}$ during pre-monsoon and between 320.0 and $1526.0 \mathrm{mg} / \mathrm{l}$ with an average of 861.0 $\mathrm{mg} / \mathrm{l}$ during post-monsoon season. Higher total dissolved solids $(3757.0 \mathrm{mg} / \mathrm{L})$ observed in sample no. 18 (Kalpakkam) irrespective of seasons indicate groundwater deterioration due to a seawater intrusion phenomenon (Srinivasamoorthy et al. 2012; Venkatramanan et al. 2017; Senthilkumar et al. 2019; Gopinath et al. 2019). This sample location is situated $9.5 \mathrm{~km}$ away from the coast in the centraleastern part of this area.

Total dissolved solids are classified into four different categories based on Davis and DeWiest (1966) for drinking and agricultural fitness (Fig. 3 a and b) such as that desirable for drinking $(500.0 \mathrm{mg} / \mathrm{L})$ and permissible for drinking (500.0-
$1000.0 \mathrm{mg} / \mathrm{L})$. Water covered by the west and entire central regions irrespective of seasons is useful for irrigation (1000.0 $3000.0 \mathrm{mg} / \mathrm{L}$ ), and water covered by the entire eastern region is unfit for irrigation and drinking $(>3000.0 \mathrm{mg} / \mathrm{L})$ purposes as noted in only sample location 18 during the PRM season. In Table 2, samples representing hard rock aquifers $(n=13)$ are desirable and permissible for drinking and useful for irrigation purposes irrespective of the seasons. In sedimentary aquifers $(n=42)$, about $29 \%$ of the samples are desirable for drinking irrespective of seasons, and about $33 \%$ of the samples are within the permissible state during the post-monsoon but found to be increased by $38 \%$ during the post-monsoon time. About $36 \%$ of the samples for the period of pre-monsoon are suggested to be useful for agricultural utilities and that trend decreased up to $31 \%$ during the post-monsoon season, which might be due to the influence of recently recharged precipitated water to the aquifers. Sample no. 18 alone is found to be unsuitable for irrigation and drinking utilities during both the seasons which might be due to heavier groundwater extraction resulting in seawater intrusion into the aquifers (CGWB 2007).

The ascendancy of the chief elements follow the array $\mathrm{Na}^{+}$ $>\mathrm{Ca}^{2+}>\mathrm{Mg}^{2+}>\mathrm{K}^{+}$and $\mathrm{HCO}_{3}{ }^{-}>\mathrm{Cl}^{-}>\mathrm{SO}_{4}{ }^{-}>\mathrm{NO}_{3}{ }^{-}$during both the seasons in hard rock aquifers, and in sedimentary aquifers, the ions follow the array $\mathrm{Na}^{+}>\mathrm{Ca}^{2+}>\mathrm{Mg}^{2+}>\mathrm{K}^{+}$ and $\mathrm{Cl}^{-}>\mathrm{HCO}_{3}{ }^{-}>\mathrm{SO}_{4}{ }^{-}>\mathrm{NO}_{3}{ }^{-}$during $\mathrm{PRM}$, but during POM, the varying trend is observed as $\mathrm{Ca}^{2+}>\mathrm{Na}^{+}>\mathrm{Mg}^{2+}>\mathrm{K}^{+}$ and $\mathrm{Cl}^{-}>\mathrm{HCO}_{3}{ }^{-}>\mathrm{SO}_{4}{ }^{-}>\mathrm{NO}_{3}{ }^{-} . \mathrm{Na}^{+}$within hard rock samples ranges between 27.0 and $164.0 \mathrm{mg} / \mathrm{l}$ with a mean value of $113.0 \mathrm{mg} / \mathrm{l}$ during pre-monsoon and between 57.0 and $173.0 \mathrm{mg} / \mathrm{l}$ with an average of $117.0 \mathrm{mg} / \mathrm{l}$, which is higher than that observed during the post-monsoon season indicating the influence of silicate weathering process from $\mathrm{Na}$-rich minerals like plagioclase and pyroxene (Vasanthavigar et al. 
Fig. 3 a Spatial distributions of TDS (Davis and DeWiest 1966) - PRM, b Spatial distributions of TDS (Davis and DeWiest 1966)-POM
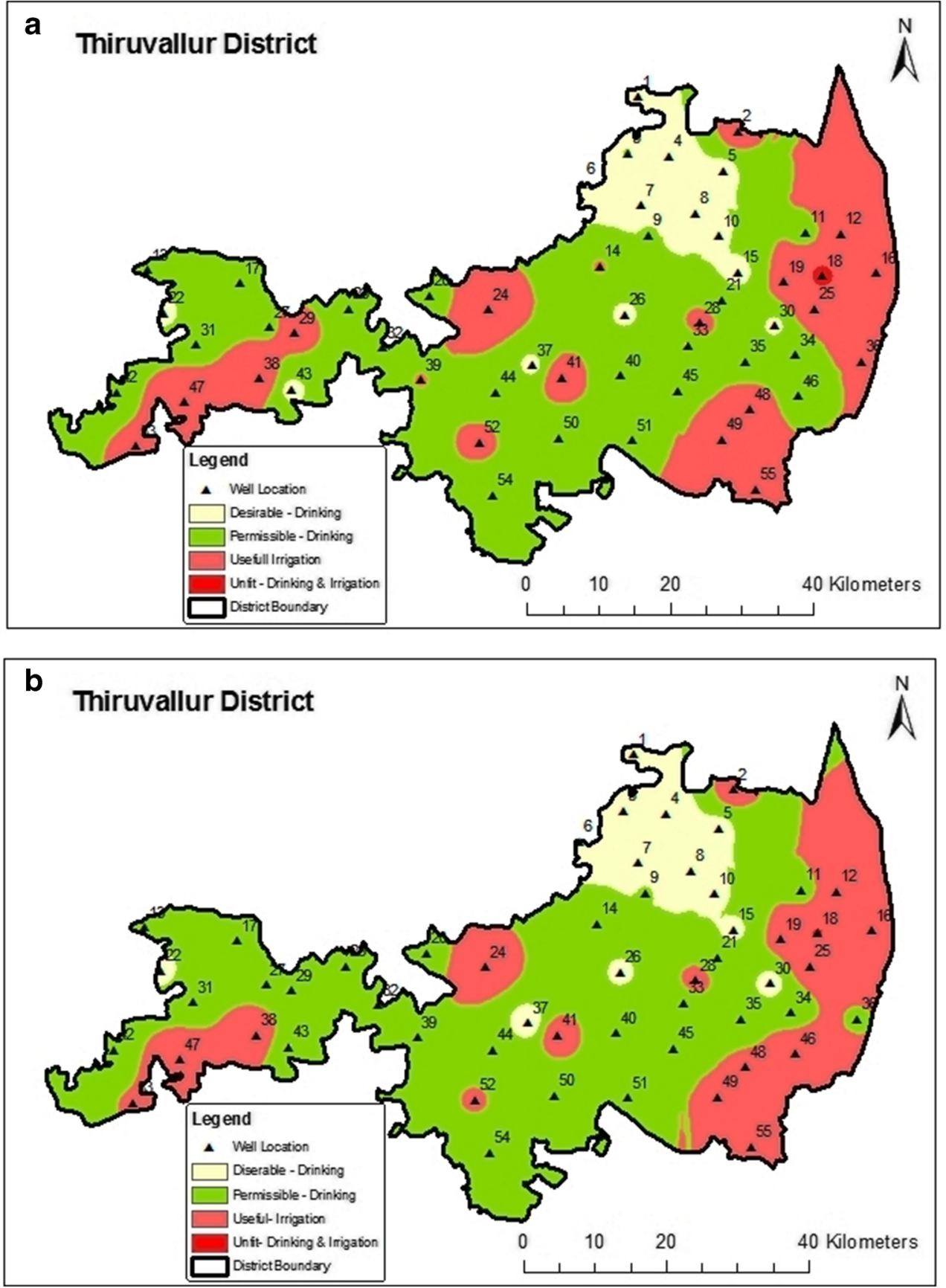

2012; Safei et al. 2015; Vinnarasi et al. 2020). In sedimentary aquifers, during PRM, sodium ranges between 6.0 and 382.0 $\mathrm{mg} / \mathrm{l}$ with a mean of 111.0 , and during POM, the results range from 8.0 to $259.0 \mathrm{mg} / 1$ with common of $103.0 \mathrm{mg} / \mathrm{l}$, suggesting a higher concentration during PRM might be due to the weathering of plagioclase feldspar and seawater intrusion (Chidambaram et al. 2010; Gopinath et al. 2019). As per the WHO (2011) guidelines, the highest acceptable edge for sodium and calcium concentration in water intake is $200.0 \mathrm{mg} / 1$ and a large amount of the samples irrespective of litho units; sodium is found to be within the permissible level and only sample nos. 18 and 55 are beyond the acceptable edge in view of seasonal variations. $\mathrm{Ca}^{+}$in hard rock aquifers range between 27.0 and $108.0 \mathrm{mg} / \mathrm{l}$ with common of $74.0 \mathrm{mg} / \mathrm{l}$ and between 31.0 and $146.0 \mathrm{mg} / \mathrm{l}$ with an average of $82.0 \mathrm{mg} / \mathrm{l}$ during PRM and POM seasons, respectively. In sedimentary aquifers for the period of PRM and POM, Ca values range from 11.0 to $306.0 \mathrm{mg} / \mathrm{l}$ with common value of 69.0 and from 17.0 to $600.0 \mathrm{mg} / 1$ with common of $82.0 \mathrm{mg} / \mathrm{l}$, respectively. Higher values noted during POM might be appropriate to dissolution and precipitation of $\mathrm{CaCO}_{3}$ with $\mathrm{Ca} \mathrm{Mg}\left(\mathrm{CO}_{3}\right)_{2}$ into aquifer recharge in the eastern portion of this area. Compared with the WHO (2011) standards, calcium is found to be inside the most permissible restrictions apart from 
Table 2 Groundwater quality on TDS(mg/l) for drinking and Irrigation purposes (Davis and DeWiest (1966)

\begin{tabular}{|c|c|c|c|c|c|}
\hline Range & Classification & PRM & $\%$ of samples & POM & $\%$ of samples \\
\hline \multicolumn{6}{|c|}{ Hard rock terrain samples } \\
\hline$<500$ & Desirable to drinking water & 22,43 & 15 & 22,43 & 15 \\
\hline $500-1000$ & Permissible for drinking water & $13,17,23,27,31,32,42$ & 54 & $13,17,23,27,29,31,32,42$ & 62 \\
\hline $1000-3000$ & Useful for irrigation & $29,38,47,53$ & 31 & $38,47,53$ & 23 \\
\hline$>3000$ & Unsuitable for drinking and irrigation & - & - & - & - \\
\hline \multicolumn{6}{|c|}{ Sedimentary terrain samples } \\
\hline$<500$ & Desirable to drinking water & $1,4-8,10,15,26,30,33,37$ & 29 & $1,3-8,10,15,26,30,37$ & 29 \\
\hline $500-1000$ & Permissible for drinking water & $\begin{array}{l}3,9,11,20,21,34,35,40 \\
\quad 44-46,50,51,54\end{array}$ & 33 & $\begin{array}{l}9,11,14,20,21,33-36,39,40 \\
\quad 44,45,50,51,54\end{array}$ & 38 \\
\hline $1000-3000$ & Useful for irrigation & $\begin{array}{c}2,12,14,16,19,24,25,28 \\
36,39,41,48,49,52,55\end{array}$ & 36 & $\begin{array}{l}2,12,16,19,24,25,28,41,46,48 \\
\quad 49,52,53\end{array}$ & 31 \\
\hline$>3000$ & Unsuitable for drinking and irrigation & 18 & 2 & 18 & 2 \\
\hline
\end{tabular}

location no. 18 that exceeded the limits. $\mathrm{K}^{+}$ion varied from 12.0 to $17.0 \mathrm{mg} / \mathrm{l}$ with an average of $48.0 \mathrm{mg} / \mathrm{l}$ and from 22.0 to $74.0 \mathrm{mg} / \mathrm{l}$ with a mean value of $50.0 \mathrm{mg} / \mathrm{l}$ during PRM and POM seasons in hard rock aquifers respectively. In sedimentary aquifer, values range from 2.0 to $164.0 \mathrm{mg} / \mathrm{l}$ and a mean of $47.0 \mathrm{mg} / \mathrm{l}$ for the period of PRM and between 3.0 and 111.0 $\mathrm{mg} / \mathrm{l}$ with a mean of $44.0 \mathrm{mg} / \mathrm{l}$ during POM. Higher $\mathrm{K}^{+}$is more prominent during POM which might be due to weathering of clay minerals and mica from sedimentary formation and anthropogenic activity. The main anthropogenic sources are (1) solicitation of droppings (either animal or artificial) in agricultural areas and (2) leaky sewer systems in the urban areas of the present study area (Gopinath et al. 2016 and 2019). Magnesium in hard rock aquifers ranges from 19.0 to $88.0 \mathrm{mg} / \mathrm{l}$ with an average value of $40.0 \mathrm{mg} / \mathrm{l}$ and from 17.0 to $88.0 \mathrm{mg} / \mathrm{l}$ with a mean of $35.0 \mathrm{mg} / \mathrm{l}$ during PRM and POM, respectively. In sedimentary samples, the value ranges from 7.0 to $252.0 \mathrm{mg} / 1$ and 6.0 to $116.0 \mathrm{mg} / 1$ with an average of 37.0 and $29.0 \mathrm{mg} / \mathrm{l}$, respectively, during PRM and POM distinctively. Every sample location falls under the highest permissible level compared with WHO $2011(150 \mathrm{mg} / \mathrm{l})$ for magnesium, except sample 18 which exceeded the limit during the PRM season. The higher magnesium observed in sedimentary samples during PRM might be due to leaching of silicate, dolomite, and sulfate minerals identified from the lithology of the study area (Appelo and Postma 2005).

Among the anions, $\mathrm{Cl}^{-}$acts an important part in determining the groundwater geochemistry. Higher $\mathrm{Cl}^{-}$in consumption water causes saline to feel and have laxative result (Bhardwaj and Singh 2010). In the study area, chloride in hard rock aquifers ranges between 25.0 and $360.0 \mathrm{mg} / \mathrm{l}$ with an average of $226.0 \mathrm{mg} / \mathrm{l}$ during PRM, and during POM, the

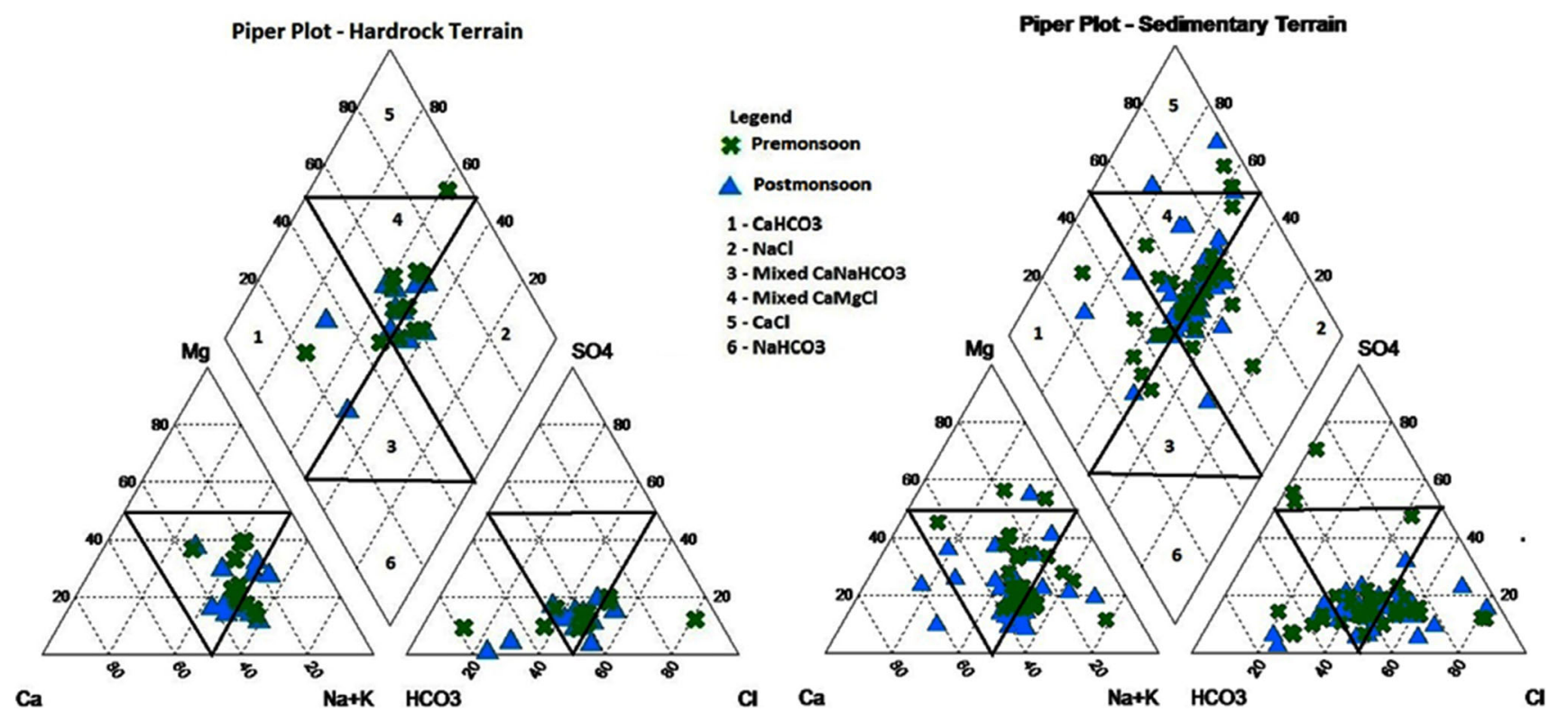

Fig. 4 Piper diagram 
Table 3 Water quality index and relative weight

\begin{tabular}{llll}
\hline Chemical parameters & WHO (2004) & Weight $\left(\mathrm{W}_{\mathrm{i}}\right)$ & $\begin{array}{l}\text { Relative weight } \\
\left(\mathrm{W}_{\mathrm{i}}\right)=\frac{W_{i}}{\sum_{i=1}^{n} w_{i}}\end{array}$ \\
\hline Total dissolved solids (mg/l) & 500 & & 0.152 \\
Calcium (mg/l) & 100 & 5 & 0.152 \\
Magnesium (mg/l) & 50 & 5 & 0.152 \\
Sodium (mg/l) & 200 & 5 & 0.121 \\
Potassium (mg/l) & 20 & 4 & 0.047 \\
Bicarbonate (mg/l) & 125 & 2 & 0.121 \\
Chloride (mg/l) & 250 & 4 & 0.091 \\
Sulfate $(\mathrm{mg} / \mathrm{l})$ & 200 & 3 & 0.091 \\
Nitrate $(\mathrm{mg} / \mathrm{l})$ & 45 & 3 & 0.091 \\
& & 3 & $\sum w_{i} 1.018$ \\
\hline
\end{tabular}

value ranges between 60.0 and $479.0 \mathrm{mg} / \mathrm{l}$ with an average of $224.0 \mathrm{mg} / \mathrm{l}$, whereas in sedimentary aquifers, the values ranged between 18.0 and $1702.0 \mathrm{mg} / \mathrm{l}$ with a mean of 241.0 $\mathrm{mg} / \mathrm{l}$ and from 18.0 to $1453.0 \mathrm{mg} / \mathrm{l}$ with an average of 231.0 $\mathrm{mg} / \mathrm{l}$ during the PRM and POM seasons correspondingly. Only $31 \%$ of the samples are higher than the permissible value $(250.0 \mathrm{mg} / \mathrm{L})$ in comparison with the WHO (2011) standard during PRM, whereas during POM, the percentage of samples decreased up to $27 \%$. Higher $\mathrm{Cl}^{-}$in groundwater samples in the coastal terrains of this region represents the significance of seawater disturbance, owed to excess withdrawal (Srinivasamoorthy et al. 2011; Mondal et al. 2011; Freeze and Cherry 1979; Gopinath et al. 2016; Senthilkumar et al. 2019), and higher values also confined to hard rock aquifers might be due to base ion exchange and irrigation return flow activities (Vengosh et al. 2002). $\mathrm{HCO}_{3}{ }^{-}$is the next dominant anion, found to be higher $(641.0 \mathrm{mg} / \mathrm{l})$ during the POM season in hard rock aquifers, and in sedimentary formations, higher concentration $(695.0 \mathrm{mg} / \mathrm{l})$ is noted during PRM season. The carbonate dissolution and silicate weathering is the mainly occur of soil $\mathrm{CO}_{2}$ releasing $\mathrm{HCO}_{3}{ }^{-}$were main key to presence of high bicarbonate in groundwater (Moquet et al. 2011; Narsimha and Sudarshan 2017). When compared with the WHO (2011) guideline for bicarbonate's (300 mg/l) most tolerable limit, about $38 \%$ of the samples in sedimentary aquifers are beyond the limit, but in hard rock formations, about $69 \%$ of the samples exceed the limit irrespective of the seasons. The $\mathrm{SO}_{4}{ }^{-}$ion value in the hard rock region ranges from 23.0 to $178.0 \mathrm{mg} / 1$ with an average of $84.0 \mathrm{mg} / 1$ during PRM, and a slight decrease is observed from 4.0 to $178.0 \mathrm{mg} / \mathrm{l}$ with a mean of $79.0 \mathrm{mg} / \mathrm{l}$ during POM. In sedimentary aquifers, the value ranges from 12.0 to $422.0 \mathrm{mg} / \mathrm{l}$ with an average of $96.0 \mathrm{mg} / \mathrm{l}$ during PRM and from 3.0 to $384.0 \mathrm{mg} / \mathrm{l}$ with an average of $95.0 \mathrm{mg} / \mathrm{l}$ for POM. $\mathrm{SO}_{4}{ }^{-}$in all the samples confined to hard rock aquifers were below the desirable limit of $200.0 \mathrm{mg} / \mathrm{l}$ irrespective of the seasons, whereas in sedimentary aquifers during PRM, they are within the permissible limits, and just $12 \%$ of POM samples exceed the permissible boundary. The

Table 4 WQI range, type of water, and percentage of the water sample during PRM and POM

\begin{tabular}{|c|c|c|c|c|c|}
\hline \multirow[t]{2}{*}{ Range } & \multirow[t]{2}{*}{ Type } & \multicolumn{2}{|c|}{ Hard rock terrain samples } & \multicolumn{2}{|l|}{ Sedimentary terrain samples } \\
\hline & & PRM & POM & PRM & POM \\
\hline$<50$ & Excellent water & $43(7.5 \%)$ & - & $4,6-8,15,30,37(17 \%)$ & $1,6,8,15,30,37(17 \%)$ \\
\hline $50-100$ & Good water & $\begin{array}{l}13,17,22,29,32 \\
\quad(39 \%)\end{array}$ & $13,22,32(23 \%)$ & $\begin{array}{l}1,3,5,9-11,26,34,35,40,46,50 \\
(29 \%)\end{array}$ & $\begin{array}{l}3-5,9-11,26,33-35,40,50 \\
\quad(29 \%)\end{array}$ \\
\hline $\begin{array}{l}100- \\
200\end{array}$ & Poor water & $\begin{array}{l}23,27,31,42,47,53 \\
\quad(46 \%)\end{array}$ & $\begin{array}{l}17,23,27,29 \\
31,42,43,47,53 \\
\quad(69.5 \%)\end{array}$ & $\begin{array}{l}2,14,16,19-21,25,28,33,36 \\
\quad 39,44,45,49,51,52,54,55 \\
\quad(43 \%)\end{array}$ & $\begin{array}{l}2,14,16,19-21,25,28,36,39, \\
\quad 41, \\
\quad 44,45,48,49,51,52,54, \\
55(45 \%)\end{array}$ \\
\hline $\begin{array}{l}200- \\
300\end{array}$ & Very poor water & $38(7.5 \%)$ & $38(7.5 \%)$ & $12,24,41,48(9 \%)$ & $12,24,46(7 \%)$ \\
\hline$>300$ & $\begin{array}{l}\text { Unsuitable for } \\
\text { drinking } \\
\text { purposes }\end{array}$ & - & - & $18(2 \%)$ & $18(2 \%)$ \\
\hline
\end{tabular}


Fig. 5 a Spatial distribution map of WQI-PRM, b Spatial distribution map of WQI-POM
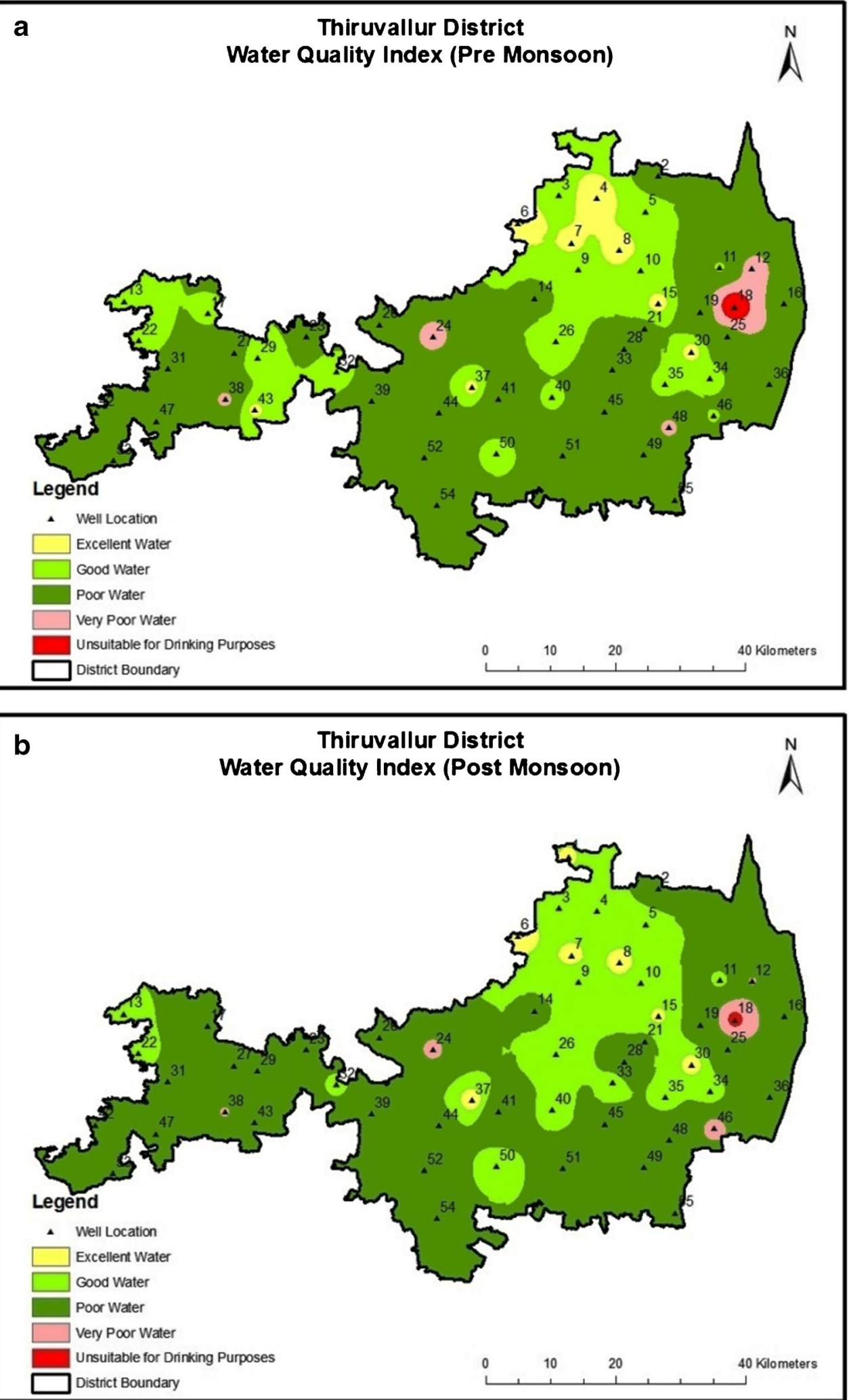

presence of higher $\mathrm{SO}_{4}{ }^{-}$in drinking water will lead to respiratory-related problems (Subba Rao 1993). The major reason for higher sulfate in sedimentary environment is the availability of gypsum, anhydrite, and oxidation of sulfate minerals from basement rock (Han et al. 2016). $\mathrm{NO}_{3}{ }^{-}$is the least dominant ion in hard rock aquifer samples irrespective of seasons ranging between $<0 \mathrm{mg} / 1$ and $89.0 \mathrm{mg} / 1$ with average values of $27.0 \mathrm{mg} / \mathrm{l}$ and $10.0 \mathrm{mg} / \mathrm{l}$ to $70.0 \mathrm{mg} / \mathrm{l}$ with a mean 
value of $30.0 \mathrm{mg} / \mathrm{l}$. In sedimentary aquifers, the value ranges from 0 to $111.0 \mathrm{mg} / 1$ with average of $23.0 \mathrm{mg} / 1$ during PRM, and increase in value was observed during POM from 4.0 to $199.0 \mathrm{mg} / \mathrm{l}$ with a mean value of $28.0 \mathrm{mg} / \mathrm{l}$. Higher nitrate $(199.0 \mathrm{mg} / \mathrm{l})$ is observed in location 45 irrespective of seasons, and its long-term consumption may lead to methemoglobinemia and gastric cancer (Naidu et al. 1998; Chen et al. 2017). Sources of nitrate might be derived from animal wastages and festering tank leakages, poultry farms, irrigation practices, and decomposing of natural domestic wastes (Narsimha and Sudarshan 2017). According to WHO (2011), the maximum permissible level for nitrate is $45 \mathrm{mg} / \mathrm{l}$, where about $92 \%$ of the hard rock samples were under the permissible limit during both the seasons and $90 \%$ of the sedimentary samples were found to be below the permissible boundary during PRM and POM seasons.

\section{Piper classification}

Important ions like $\mathrm{Na}^{+}, \mathrm{K}^{+}, \mathrm{Ca}^{2+}, \mathrm{Mg}^{2+}, \mathrm{Cl}^{-}, \mathrm{HCO}_{3}{ }^{-}, \mathrm{CO}_{3}{ }^{2-}$ and $\mathrm{SO}_{4}{ }^{2-}$ (in meq/l) were charted in a piper trilinear diagram (Piper 1944) to estimate the hydrochemical facies of water through the PRM and POM periods in view of terrain variations, as these ions are the more common components in controlling groundwater geochemistry. Piper plot (Fig. 4) signifies majority of groundwater samples drop in the field of alkalis $\left(\mathrm{Na}^{+}, \mathrm{K}^{+}\right)$dominating over the alkaline earth metals $\left(\mathrm{Ca}^{2+}, \mathrm{Mg}^{2+}\right)$ and strong acid $\left(\mathrm{Cl}^{-}, \mathrm{SO}_{4}{ }^{2-}\right)$ goes beyond the weak acid $\left(\mathrm{CO}_{3}{ }^{2-}, \mathrm{HCO}_{3}{ }^{-}\right)$, and few samples also represent neutral acids $\left(\mathrm{HCO}_{3}{ }^{-}, \mathrm{Cl}^{-}\right)$. Samples from hard rock aquifers shows the order of Mixed $\mathrm{CaMgCl}>\mathrm{NaCl}>\mathrm{CaHCO}_{3}>\mathrm{CaCl}$. Most of samples are clustered at the facies of mixed $\mathrm{Ca}-\mathrm{Mg}-$ $\mathrm{Cl}$ and $\mathrm{NaCl}$ types during both PRM and POM seasons indicating older groundwater owed to expand rock water contact with superior $\mathrm{Na}^{+}$leached from feldspar-rich reserves and $\mathrm{Cl}^{-}$ derived from anthropogenic activity (Saravanan et al. 2016). In sedimentary terrain, the leading water types follow the array of $\mathrm{NaCl}>$ Mixed $\mathrm{CaMgCl}>\mathrm{CaHCO}_{3}>\mathrm{CaCl}>$ mixed $\mathrm{CaNaHCO}_{3}$. Majority of the samples are found to be scattered in $\mathrm{Na}-\mathrm{Cl}$ and mixed $\mathrm{CaMgCl}$ facies during both the seasons, revealing the prominence of seawater intrusion (Senthilkumar et al. 2019) restricted to the coastal traces of the study area. Fewer representations are also noted in $\mathrm{Ca}-\mathrm{HCO}_{3}$ and mixed $\mathrm{CaNaHCO}_{3}$-type facies during PRM season indicating the recent recharge of terrestrial water restricted to the western portion of the study area encompassed by sedimentary aquifers.

\section{WQI}

The demarcation of groundwater quality for drinking water suitability mostly used WQI parameter by Vasanthavigar et al. (2010), Yidana et al. (2010), Oinam et al. (2012), Thivya et al. (2013), Bodrud-Doza et al. (2016), and Gopinath et al. (2018). WQI is defined as a rating technique that provides an overall impact of individual water quality parameters on the overall quality of water for human consumption (Mitra et al. 2006). The drinking utility standards recommended by WHO (2011) and BIS (2003) have been considered for calculating the water quality index. For the calculation of the WQI of 9 parameters (total dissolved solids, $\mathrm{Na}^{+}, \mathrm{K}^{+}, \mathrm{Ca}^{2+}, \mathrm{Mg}^{2+}$, $\mathrm{Cl}^{-}, \mathrm{HCO}_{3}{ }^{-}, \mathrm{SO}_{4}{ }^{2-}$, and $\mathrm{NO}_{3}{ }^{-}$as a whole), a weight (according to its relative importance in the overall quality of water for drinking purposes) is assigned (Table 3). The water quality index provides the overall effect of individual water quality for drinking. It is classified into five, such as excellent $(>50)$, good (51-100), poor (101$200)$, very poor (201-300), and unsuitable for drinking $(<300)$. Depending on the importance of the water quality

Table 5 Classification of groundwater based on Total Hardness (TH) (Sawyer and McCarty 1967)

\begin{tabular}{|c|c|c|c|c|c|}
\hline $\mathrm{TH}(\mathrm{mg} / \mathrm{l})$ & Water classification & PRM & $\%$ & POM & $\%$ \\
\hline \multicolumn{6}{|c|}{ Hard rock terrain samples } \\
\hline$<75$ & Soft water & - & 0 & - & 0 \\
\hline $75-150$ & Moderate hard water & - & 0 & - & 0 \\
\hline $150-300$ & Hard water & $13,17,22,23,43,53$ & 46 & $13,23,29,31,32,43,53$ & 54 \\
\hline$>300$ & Very hard water & $27,29,31,32,38,42,47$ & 54 & $17,22,27,38,42,47$ & 46 \\
\hline \multicolumn{6}{|c|}{ Sedimentary terrain samples } \\
\hline$<75$ & Soft water & 4,6 & 5 & 30 & 2 \\
\hline $75-150$ & Moderate hard water & $1,5,7,8,15,26,30,37$ & 19 & $1,4,5,10,26,33,37$ & 17 \\
\hline $150-300$ & Hard water & $\begin{array}{l}3,9,10,11,14,20,21,33 \\
34,35,40,46,50,51,54,55\end{array}$ & 38 & $\begin{array}{l}3,6,7,8,9,11,14,15,20,21 \\
\quad 34,35,40,50,51,54\end{array}$ & 38 \\
\hline$>300$ & Very hard water & $\begin{array}{l}2,12,16,18,19,24,25,28,36 \\
39,41,44,45,48,49,52\end{array}$ & 38 & $\begin{array}{c}2,12,16,18,19,24,25,28,36,39 \\
41,44,45,46,48,49,52,55\end{array}$ & 43 \\
\hline
\end{tabular}


parameters, maximum and minimum weights were assigned. The maximum weight of 5 was assigned to the parameters total dissolved solids, chloride, and nitrate, as they play an important role in groundwater quality (Srinivasamoorthy et al. 2008; Vasanthavigar et al. 2010; Krishnakumar et al. 2013). Other parameters such as bicarbonate, sodium, potassium, calcium, and magnesium were assigned weights $1-4$ based on their importance in the evaluation of water quality. After assessing the weights for each parameter, the relative weights were calculated (Table 3). In addition, a quality rating (QI) is assigned to each rating based on the concentration of samples $\left(C_{i}\right)$ divided by the drinking water quality standard $\left(S_{i}\right)$ using the following ratings:

$q_{i}=\left(C_{i} / S_{i}\right) \times 100$

At last, WQI is calculated according to below method:

$S I_{i}=W_{i} / q_{i} W Q I=\sum S I_{i}$

where $S I_{i}$ is the sub-index of $i$ th factor. $W_{i}$ is the relative weight

Consequently, the quality of water score of the studied samples obtained ranges from 21 to 443 during the PRM period and
Fig. 6 a Spatial distribution map of total hardness (TH) - PRM, b Spatial distribution map of total hardness $(\mathrm{TH})$ - POM
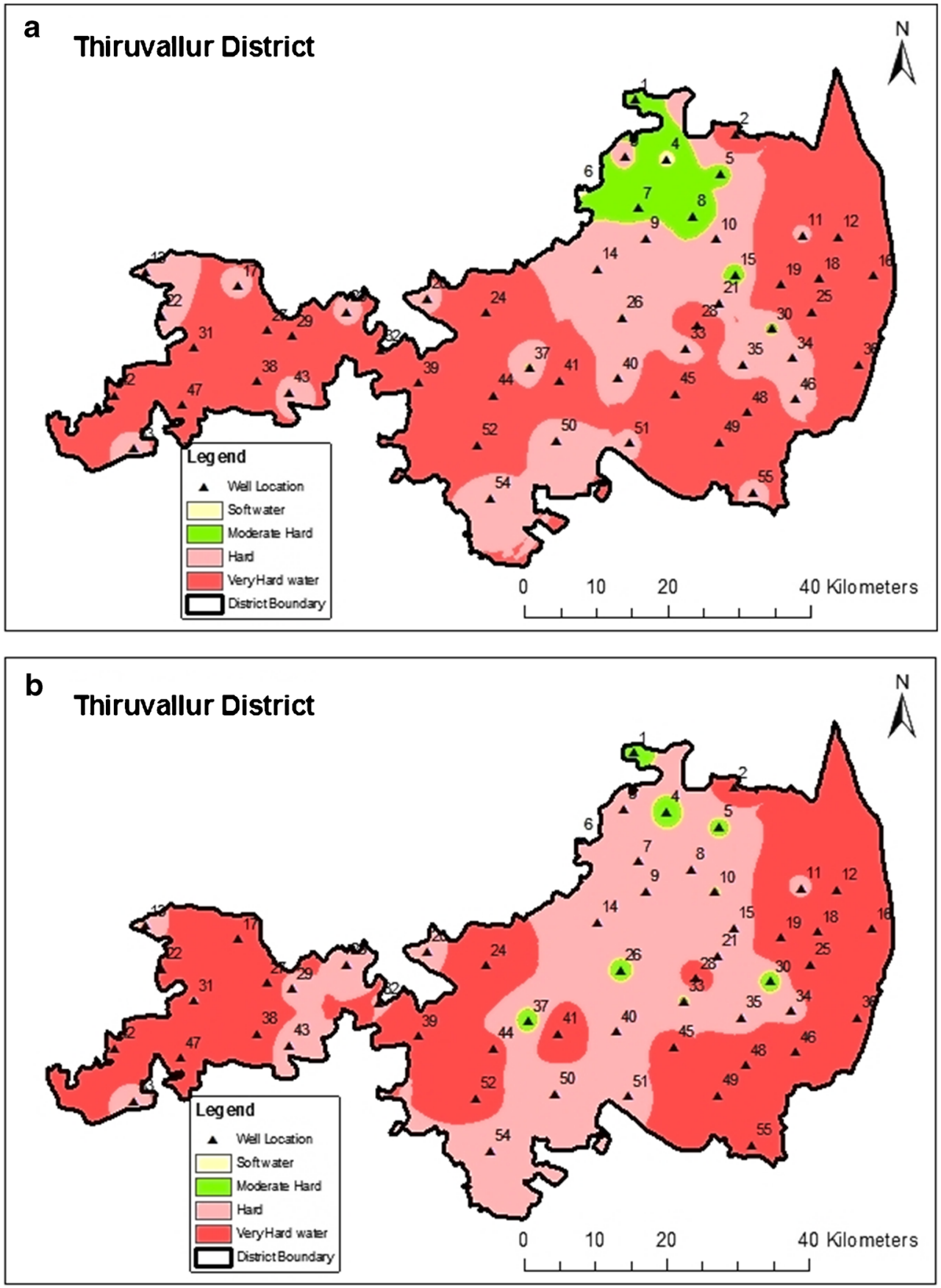
decreases from 17 to 340 during POM seasons. The WQI assortment, water type, and percentage of the sample have been classified in Table 4, and its spatial distribution maps are shown in Fig. 5a for PRM and Fig. 5b for POM season, revealing that the excellent and good water types occupied the northwestern part and the remaining area is covered by poor to very poor water types irrespective of season. In hard rock samples, about $46 \%$ of the samples were established to be excellent to good category and $54 \%$ were poor to very poor category for drinking during PRM, and for POM seasons, $23 \%$ of the samples were good for drinking utility and $77 \%$ were found to be poor to very poor category. In sedimentary aquifers, about $46 \%$ of samples represents excellent to good water type during PRM and POM seasons, but the poor water type during PRM and POM periods were represented by $43 \%$ and $45 \%$ of water samples respectively. Very poor water type is found represented by $9 \%$ and $7 \%$ of samples at the time of PRM and POM correspondingly, but sample no. 18 is found to be unsuitable for drinking purposes irrespective of seasons representing sedimentary aquifers. Comparison between spatial distribution maps of total dissolved solids with WQI reveals that good-quality water occurred in the northern and northwestern parts of the study region irrespective of the seasons. The poor and very poor quality of groundwater identified as packets for the entire study area might be due to ion exchange process and unplanned irrigation practice (Vasanthavigar et al. 2010; Bodrud-Doza et al. 2016; Gopinath et al. 2018).

\section{Total hardness}

The total hardness in ground water is due to increase in $\mathrm{Mg}_{2}{ }^{+}$, $\mathrm{Ca}_{2}{ }^{+}, \mathrm{HCO}_{3}{ }^{-}, \mathrm{Cl}^{-}$, and $\mathrm{SO}_{4}{ }^{-}$ions in water. Based on Sawyer and McCarty (1967), total hardness (TH) classification of water in hard rock terrain shows hard water type for about $46 \%$ and 54\% of the samples during PRM and POM respectively and very hard water types represented by $54 \%$ and $46 \%$ of samples during PRM and POM season in that order (Table 5). In sedimentary terrain, about $5 \%$ of samples are observed to be soft, $19 \%$ of the sample as moderately hard water, $38 \%$ as hard water type, and 38\% as very hard water type during PRM period. During POM season, $2 \%$ of the sample represents soft, $17 \%$ as moderate, $38 \%$ as hard water, and the remaining $43 \%$ as very hard water. The spatial delivery of $\mathrm{TH}$ in the entire study area with respect to season is presented in Fig. $6 a$ and b. Mostly hard and very hard water types occupied the entire study area, and except small patches, moderate hard water types occupied the north-central portion during PRM and POM. Very high hard water consumption in the long term will result to many health problems to human beings (Durvey et al. 1991; Agrawal and Jagetai 1997).

\section{Water quality evaluation for irrigation}

Designing, planning, and operation of irrigation systems need for periodical supervision of groundwater quality are essential to make certain reduction of harmful salts in irrigation water (Sangodoyin and Ogedenbe 1991). The sodium adsorption ratio, residual sodium carbonate, salinity, $\mathrm{Na}^{+} \%$, permeability index (PI), Kelly's plot, and Wilcox plot are some of the parameters for delineating groundwater suitability for irrigation purposes. Surplus salinity reduces osmotic movement of plants and absorption of water and nutrients in soil (Thorne and Peterson 1954). Based on Raghunath (1987), electrical conductivity is a fine measure for salinity hazard to crops, and electrical conductivity and $\mathrm{Na}^{+}$are significant parameters to classify groundwater for irrigation utilities. According to Thorne and Peterson (1954), osmotic pressure in soil results in high salinity in water. The

Table 6 Classification of Thiruvallur district groundwater based on Na\% (Raghunath 1987)

\begin{tabular}{|c|c|c|c|c|c|}
\hline Range & Categories & PRM & $\%$ & POM & $\%$ \\
\hline \multicolumn{6}{|c|}{ Hard rock terrain samples } \\
\hline$<20$ & Excellent & - & - & - & - \\
\hline $20-40$ & Good & 43 & 8 & 22 & 8 \\
\hline $40-60$ & Permissible & $17,22,29,31,32,38,42$ & 54 & $17,27,31,38,42$ & 38 \\
\hline $60-80$ & Doubtful & $13,23,27,47,53$ & 38 & $13,23,29,32,43,47,53$ & 54 \\
\hline$>80$ & Unsuitable & - & - & - & - \\
\hline \multicolumn{6}{|c|}{ Sedimentary terrain samples } \\
\hline$<20$ & Excellent & 30 & 2 & - & - \\
\hline $20-40$ & Good & - & - & $3,6,18,30,37$ & 12 \\
\hline $40-60$ & Permissible & $\begin{array}{l}4-11,16,18-21,28,33 \\
35,37,40,44-46,52,54\end{array}$ & 55 & $\begin{array}{c}5,7,8,9,10,11,15,16,20,21,24 \\
28,35,40,44,46,48,51,52,54\end{array}$ & 48 \\
\hline $60-80$ & Doubtful & $\begin{array}{l}1,2,3,12,14,15,24,25,26 \\
34,36,39,41,48,49,50,51\end{array}$ & 41 & $\begin{array}{l}1,2,4,12,14,19,25,26,34,36 \\
\quad 39,41,45,49,50,55\end{array}$ & 38 \\
\hline$>80$ & Unsuitable & 55 & 2 & 33 & 2 \\
\hline
\end{tabular}


suitability of water for agriculture adopted by the US Salinity Laboratory is explained as follows.

\section{$\mathrm{NA}^{+} \%$}

More sodium issue in irrigated water will distress the soil permeability and is toxic to plants (Durfer and Backer 1964; Todd 1980; Bangar et al. 2008). $\mathrm{Na}^{+} \%$ can be evaluated based on Raghunath (1987), by the below equation:
$\mathrm{Na}^{+} \%=\frac{\left(\mathrm{Na}^{+}+\mathrm{K}^{+}\right) \times 100}{\left(\mathrm{Ca}^{2+}+\mathrm{Mg}^{2+}+\mathrm{Na}^{+}+\mathrm{K}^{+}\right)} \mathrm{meq} / 1$

Based on $\mathrm{Na}^{+} \%$, groundwater samples were classified into five major types as represented in Table 6 in view of lithology variations. The sodium percentage for hard rock aquifers in about $7 \%$ of the samples is doubtful during PRM, and increase in the sample amount of about $13 \%$ has been observed during POM season. The rest of the samples irrespective of seasons represent the good and permissible categories. In sedimentary
Fig. 7 a Spatial distribution map of suitability for irrigation purposes based on Na\%-PRM, $\mathbf{b}$ Spatial distribution map of suitability for irrigation purposes based on $\mathrm{Na} \%$-POM
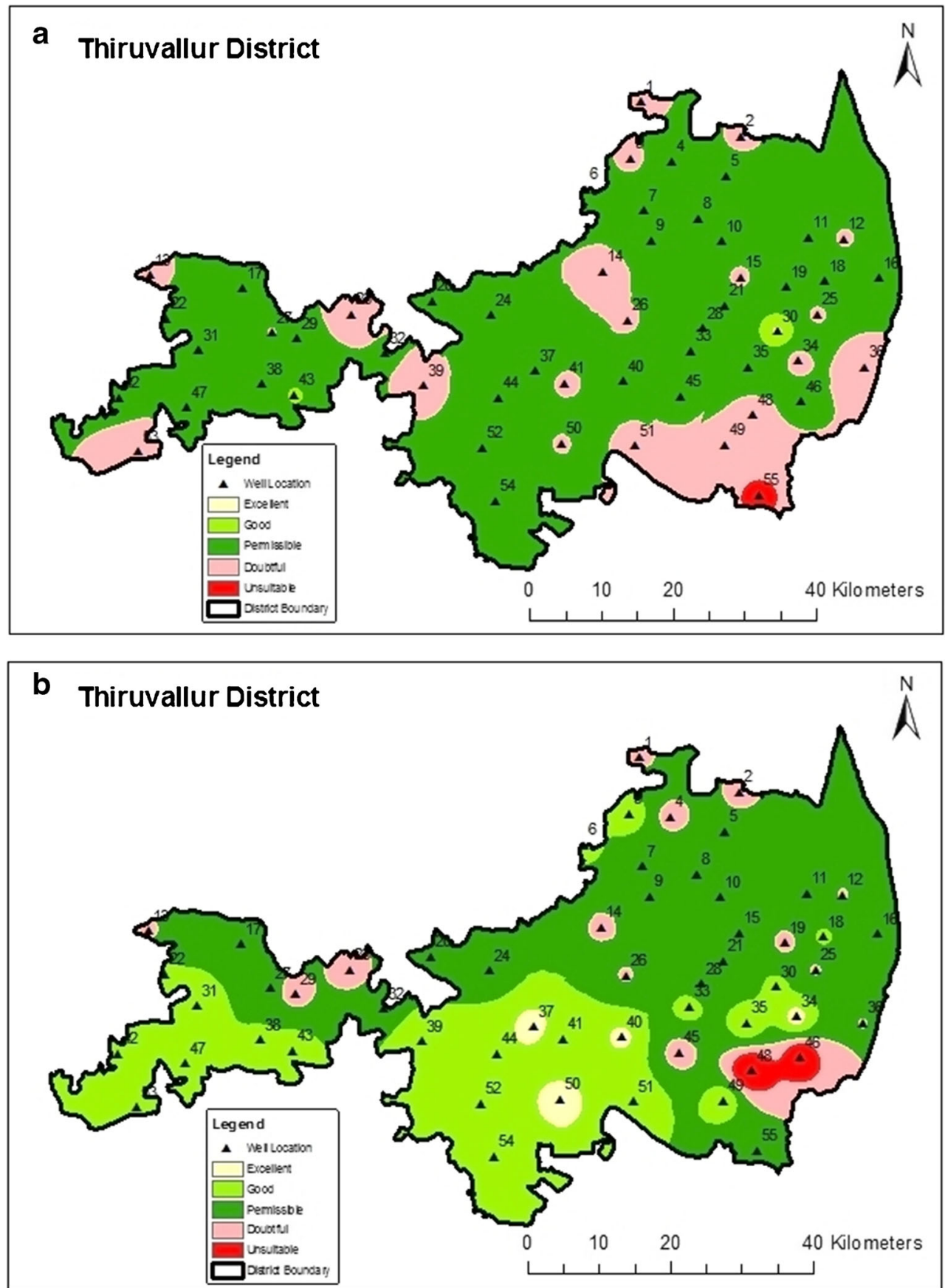
terrain, about $32 \%$ and $2 \%$ of samples are doubtful and not suitable during PRM season. During POM, about 29\% and $2 \%$ of samples are doubtful to not suitable; the rest of the samples signifies an excellent and permissible category (Fig. $7 \mathrm{a}$ and $\mathrm{b}$ ). The $\mathrm{Na}^{+} \%$ spatial distribution map for PRM period is shown in Fig. $7 \mathrm{a}$ and $\mathrm{b}$ for POM period revealing that the good and permissible types occupied the north, west, and eastern portions, but the southeastern part is covered by doubtful to unsuitable condition irrespective of season for agricultural purposes. Groundwater classification based on $\mathrm{Na}^{+} \%$ and electrical conductivity was attempted by Wilcox (1955)'s diagram for different litho-units in the study area and is represented in Fig. 8. The diagram represents the majority of hard rock samples in excellent to good and good to permissible except in few locations that represent doubtful to unsuitable for irrigation purposes irrespective of PRM and POM seasons. On the other hand, for sedimentary terrain, majority of the samples scatter in excellent to good and good to permissible irrespective of seasons. About 7 and 5 samples from the period of PRM and POM, respectively, are found to represent doubtful to unsuitable condition for irrigation utility. Samples no. 18 and 46 are unsuitable water for irrigation purposes during POM season. The agricultural yields are normally low in locations that are doubtful to unsuitable, which is due to the presence of $\mathrm{Na}$ salts and indulges osmotic effects in the soil-plant system. Excess sodium in waters produces undesirable effects on soil properties and reduces the soil permeability. The $\mathrm{Na}^{+} \%$ spatial distribution map shows that most of the location is covered by permissible category for irrigation in PRM and good to permissible category in POM season, except a few samples that are unsuitable for irrigation in the southeastern part of the study area irrespective of season. In the study area, groundwater at Ramapuram shows high $\mathrm{Na}$ which may be due to the influence of seawater, and these locations can be encouraged to irrigate salt-tolerant plants like cotton, coconut.

\section{SAR}

Sodium adsorption ratio is a significant parameter to determine the groundwater suitability for agriculture due and thus determine alkali/sodium risk to crops. Sodium adsorption ratio can be calculated by adopting the equation below where all ions are expressed in meq/l:

$\mathrm{SAR}=\frac{\mathrm{Na}^{+}}{\sqrt{\frac{\mathrm{Ca}^{2+}+\mathrm{Mg}^{2+}}{2}}}$

Based on Richard (1954)'s classification, sodium adsorption ratio values in hard rock terrain range from 1.2 to 5.24 during PRM and POM season SAR ranges from 1.74 to 5.44. On the other hand, in sedimentary aquifers, the values range from 0.31 to 14.09 in PRM and between 0.5 and 6.92 during POM season. It is noted that all the samples represent excellent category for irrigation purposes in all season with respect to litho-units except location no. 55 during PRM that represents good-quality water for irrigation utilities as represented in Tables 7 and 8. Shrinking and swelling in clayey soils will be due to sodium adsorption ratio values greater than 9, (Saleh et al. 1999). Higher sodium adsorption ratio in groundwater will develop alkaline soil (Todd 1980), with high salt leading
Wilcox - Hardrock Terrain

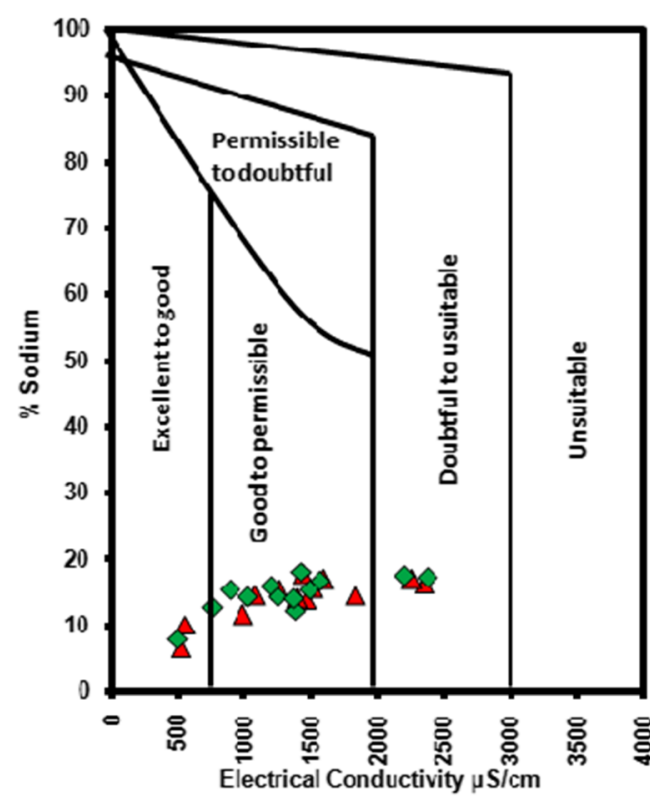

Wilcox - Sedimentary Terrain

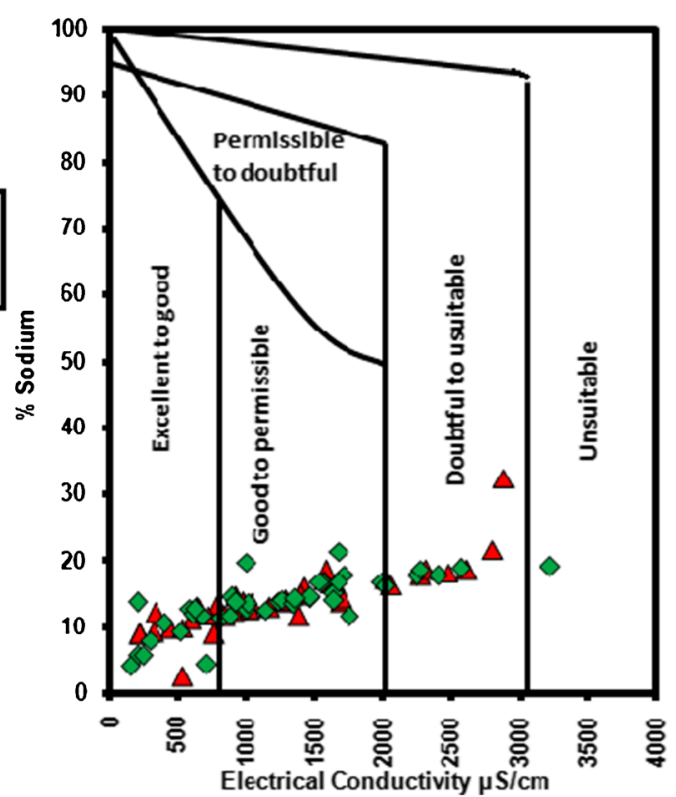

Fig. 8 Wilcox diagram for irrigation classification of groundwater during PRM and POM 
Table 7 Salinity hazard classification for Thiruvallur district

\begin{tabular}{|c|c|c|c|c|c|}
\hline \multirow[t]{2}{*}{$\mathrm{EC}$ at $25^{\circ} \mathrm{C}(\mu \mathrm{mohs} / \mathrm{cm})$} & \multirow[t]{2}{*}{ Salinity hazard } & \multicolumn{2}{|l|}{ Hard rock terrain } & \multicolumn{2}{|l|}{ Sedimentary terrain } \\
\hline & & PRM & POM & PRM & POM \\
\hline$<250$ & Excellent $(\mathrm{C} 1)$ & - & - & $4,6(5 \%)$ & $4,6,30,37(10 \%)$ \\
\hline $250-750$ & Good (C2) & $22,43(15 \%)$ & $22(7.5 \%)$ & $\begin{array}{l}1,5,7,8,10,15,34,26 \\
30,37(24 \%)\end{array}$ & $\begin{array}{l}1,3,5,7,8,10,15 \\
26(19 \%)\end{array}$ \\
\hline $750-2250$ & Permissible (C3) & $\begin{array}{l}13,17,23,27,29 \\
\quad 31,32,42 \\
53(70 \%)\end{array}$ & $\begin{array}{c}13,17,23,27,29 \\
31,32,42,43 \\
53,47(85 \%)\end{array}$ & $\begin{array}{l}3,9,11,14,16,19-21,25 \\
28,33,35,36,39,40,44 \\
46,49,52,54(55 \%)\end{array}$ & $\begin{array}{l}2,9,11,14,16,19,20, \\
21,25,28,33-36,39, \\
\quad 40,44,45,48-52,54, \\
55(59 \%)\end{array}$ \\
\hline$>2250$ & Unsuitable (C4) & $38,47(15 \%)$ & $38(7.5 \%)$ & $2,12,18,24,41,48,55(16 \%)$ & $12,18,24,41,46,(12 \%)$ \\
\hline
\end{tabular}

to saline soil. The analytical data are plotted in the USSL chart (Richards 1954) for different seasons and litho-units. Majority of the samples from hard rock terrain $(>90 \%)$ are found to represent in $\mathrm{C}_{3} \mathrm{~S}_{1}$ and few samples in $\mathrm{C}_{2} \mathrm{~S}_{1}$ irrespective of seasons, suggesting high salinity and low sodium waters. For sedimentary terrain, majority of the samples represent $\mathrm{C}_{3} \mathrm{~S}_{1}$ and $\mathrm{C}_{2} \mathrm{~S}_{1}$ type, and minor representation is also noted in $\mathrm{C}_{1} \mathrm{~S}_{1}$ and $\mathrm{C}_{4} \mathrm{~S}_{1}$ during PRM and POM. This water can be used for irrigation in any type of soil with tiny danger of transferable sodium. $\mathrm{C}_{4} \mathrm{~S}_{3}$-type water occurs at Ramapuram (sample no. 55) during PRM indicating very high salinity and high sodium, which is suitable for salt tolerance in plants. $\mathrm{C}_{4} \mathrm{~S}_{3}$-type water restricts good drainage in soils which in turn is unsuitable for irrigation (Karnath 1989; Mohan et al. 2000). The higher electrical conductivity and sodium concentrations are the result of saline soil, irrigation activities, and leaching of animal waste and other domestic wastes (Senthilkumar et al. 2014b; Gopinath and Srinivasamoorthy 2015).

\section{RSC}

The hazardous effect of $\mathrm{CO}_{3}{ }^{2-}$ and $\mathrm{HCO}_{3}{ }^{-}$along with calcium and magnesium ions is used to determine the residual sodium carbonate (Eaton 1950) calculated using the formula mentioned below (Lloyd and Heathcote 1985):

$\mathrm{RSC}=\left(\mathrm{CO}_{3}{ }^{2-}+\mathrm{HCO}_{3}^{-}\right)-\left(\mathrm{Ca}^{2+}+\mathrm{Mg}^{2+}\right)$ in values of meq

When residual sodium carbonate $<1.25$, the water is found to be safe for irrigation, and values ranging 1.25 to 2.5 mean moderate for irrigation, while greater than 2.5 groundwater seems to be unsuitable for irrigation utilities (USEPA 1999). Groundwater from this area is classified on the root of residual sodium carbonate values as terrain shown in Table 9. The residual sodium carbonate in about $85 \%$ of hard rock samples is safe during the PRM and POM seasons; $15 \%$ of the samples are moderate during PRM, and during POM, about $7.5 \%$ of the samples are found to be unsuitable for irrigation utilities. In sedimentary terrain, $98 \%$ and $93 \%$ of water samples represent safe category during both PRM and POM seasons, and the remaining $2 \%$ and $7 \%$ of samples show that continued usage of high residual sodium carbonate water will result in crop yielding and burning of plant leaves.

\section{PI}

The soil permeability index is pretentious due to utilization of water with higher $\mathrm{Na}^{+}, \mathrm{Ca}^{2+}, \mathrm{Mg}^{2+}$, and $\mathrm{HCO}_{3}{ }^{-}$content. The permeability index can be calculated using the following relationship (Doneen 1964):

$\mathrm{PI}=\frac{\left(\mathrm{Na}^{+}+\sqrt{\mathrm{HCO}_{3}}{ }^{-}\right) \times 100}{\left(\mathrm{Na}^{+}+\mathrm{Mg}^{2+}+\mathrm{Ca}^{2+}\right)}$ meq $/ 1$

Based on PI, groundwater samples are classified into three types such as class I, class II, and class III. Class I and class II waters are categorized as well for irrigation, and class III waters are unsuitable for irrigation. Bulk of samples in hard rock samples falls in class I category during PRM and POM revealing groundwater is good for irrigation purposes. In sedimentary terrain, all the samples fall in class I and class II categories, irrespective of seasons, revealing that the water is suitable for irrigation utilities except samples 15 and 33 that are class III water indicating unsuitability for irrigation utilities (Figs. 9 and 10). If evaporation-enriched irrigated water comes in the /lgroundwater zone as recharge, it will influence the irrigation

Table 8 Sodium hazard classes based on USSL classification

\begin{tabular}{|c|c|c|c|c|c|}
\hline \multirow{2}{*}{$\begin{array}{l}\text { SAR(Richards } \\
1954 \text { ) range }\end{array}$} & \multirow[t]{2}{*}{ Classification } & \multicolumn{2}{|c|}{ Hard rock terrain } & \multicolumn{2}{|c|}{ Sedimentary terrain } \\
\hline & & PRM & POM & PRM & POM \\
\hline$<10$ & Excellent & 13 & 13 & $54(98 \%)$ & $55(100 \%)$ \\
\hline 10 to 18 & Good & - & - & $1(2 \%)$ & - \\
\hline 18 to 26 & Doubtful & - & - & - & - \\
\hline$>26$ & Unsuitable & - & - & - & - \\
\hline
\end{tabular}


Table 9 Groundwater quality based on RSC carbonate

\begin{tabular}{|c|c|c|c|c|c|}
\hline $\mathrm{RSC}(\mathrm{meq} / \mathrm{l})$ & Water class & PRM & $\%$ & POM & $\%$ \\
\hline \multicolumn{6}{|c|}{ Hard rock terrain samples } \\
\hline$<1.25$ & Safe & $\begin{array}{l}13,17,22,23,29,31 \\
38,42,43,47,53\end{array}$ & 85 & $\begin{array}{l}17,22,23,27,29,31,32 \\
38,42,47,53\end{array}$ & 85 \\
\hline $1.25-2.5$ & Moderate & 27,32 & 15 & 43 & 7.5 \\
\hline$>2.5$ & Unsuitable & - & - & 13 & 7.5 \\
\hline \multicolumn{6}{|c|}{ Sedimentary terrain samples } \\
\hline$<1.25$ & Safe & $\begin{array}{l}1-12,14-16,18-21,24-26,28, \\
\quad 30,33-37,39-41,44-46,48-52,54\end{array}$ & 98 & $\begin{array}{l}1-4,6-9,11,12,14-16,18-21 \\
24-26,28,30,34-37,39-41 \\
44-46,48-52,54,55\end{array}$ & 93 \\
\hline $1.25-2.5$ & Moderate & - & 0 & 10 & 2 \\
\hline$>2.5$ & Unsuitable & 55 & 2 & 5,33 & 5 \\
\hline
\end{tabular}

practices (Rajesh et al. 2011; Parimala renganayaki and Elango 2013).

\section{Kelley's ratio}

Based on Kelly's ratio, groundwater can be classified for irrigation purposes through the relationship of $\mathrm{Na}^{+}$ions against $\mathrm{Ca}^{+}$and $\mathrm{Mg}^{+}$ions measured by Kelly (1957) as noted below:

Kelley's ratio $=\frac{\mathrm{Na}}{\mathrm{Ca}+\mathrm{Mg}} \mathrm{meq} / 1$

Kelley's ratio $>2$ indicates excess $\mathrm{Na}^{+}$in water which is unsuitable for irrigation (Table 10); ratio $<1$ is suitable for irrigation, and ranges between 1 and 2 are marginally utilized for agricultural purposes. In hard rock regions, $85 \%$ of the samples $(<1)$ are suitable for irrigation during PRM and about $77 \%$ during POM season are suitable for irrigation. The remaining $15 \%$ of the samples in PRM and $23 \%$ during POM represent a marginal category for irrigation utilities. On the other hand, in sedimentary terrain, about $91 \%$ of samples represent a suitable category through PRM and POM seasons, the and marginal category is represented by $7 \%$ and $9 \%$ of the samples during PRM and POM seasons. Only $2 \%$ of the samples during PRM season is found to be not suitable for irrigation (>2) activities. The release of $\mathrm{Na}^{+}$or $\mathrm{Ca}^{2+}$ into groundwater and the adsorption of $\mathrm{Ca}^{2+}$ or $\mathrm{Na}^{+}$are due to montmorillonite clays which are situated in the waterlogged area, marshy/swampy land, and creeks (Alison et al. 1992; Krishnakumar et al. 2013).
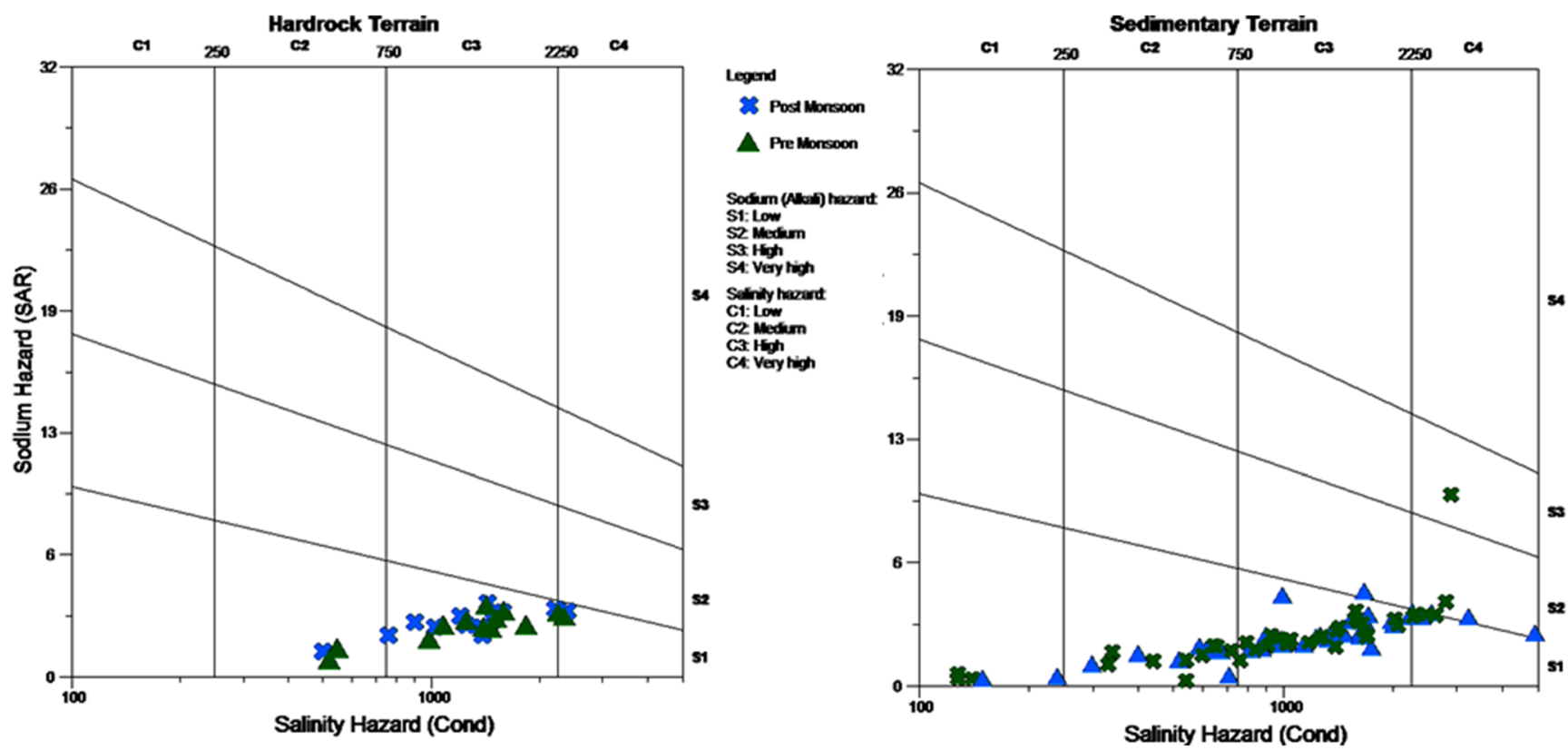

Fig. 9 USSL classification for Irrigation utility of groundwater 
Doneen Plot - Hardrock Terrain

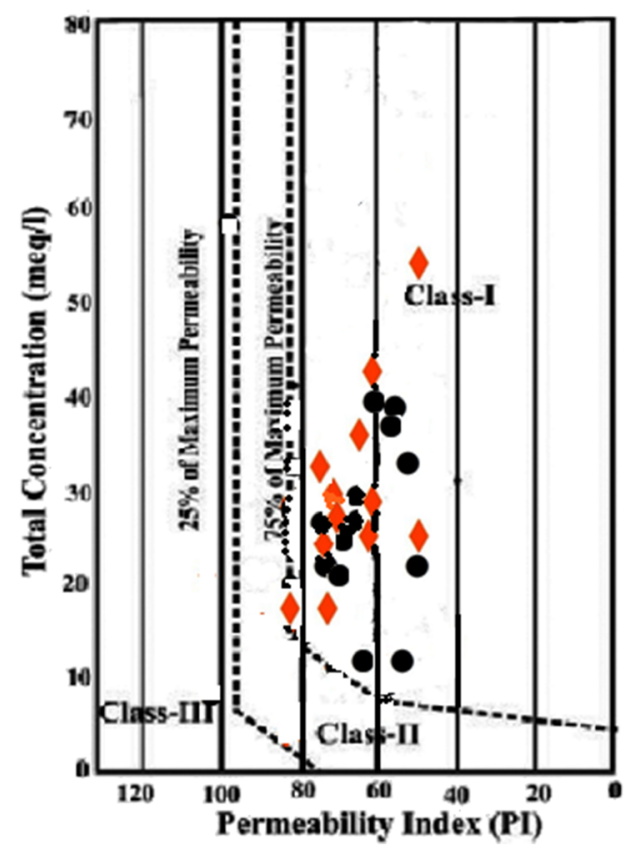

Doneen Plot - Sedimentary Terrain

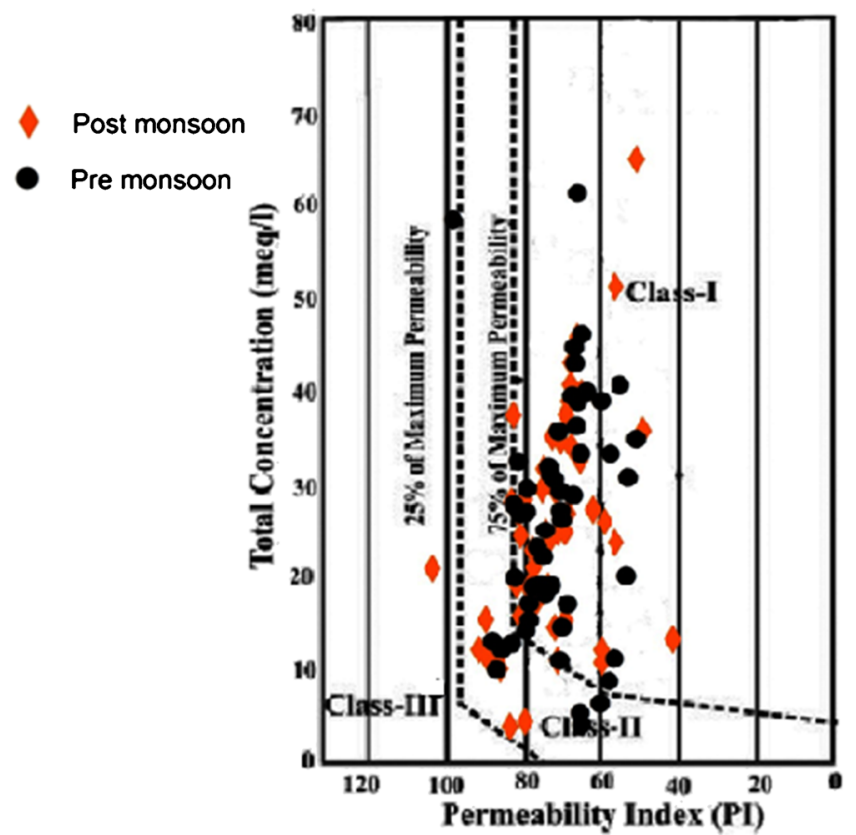

Fig. 10 Doneen's classification of irrigation water based on permeability index

\section{Conclusion}

The current understanding of groundwater quality in Thiruvallur district of Tamil Nadu, South India, for drinking and agricultural utility indicated that the water quality of the samples exceeded the BIS and WHO limits in particular locations, which have potential adverse effect on human health. Groundwater is generally alkaline, hard to very hard type, and fresh to brackish irrespective of seasons and litho-units. The dominance of major ions followed the order $\mathrm{Na}^{+}>\mathrm{Ca}^{2+}$ $>\mathrm{Mg}^{2+}>\mathrm{K}^{+}$and $\mathrm{HCO}_{3}{ }^{-}>\mathrm{Cl}^{-}>\mathrm{SO}_{4}{ }^{-}>\mathrm{NO}_{3}{ }^{-}$in hard rock samples and $\mathrm{Na}^{+}>\mathrm{Ca}^{2+}>\mathrm{Mg}^{2+}>\mathrm{K}^{+}$and $\mathrm{Cl}^{-}>\mathrm{HCO}_{3}{ }^{-}>$ $\mathrm{SO}_{4}{ }^{-}>\mathrm{NO}_{3}{ }^{-}$in sedimentary formations. Groundwater shows sodium is principal in cations and chloride in anions in sedimentary region, and $\mathrm{HCO}_{3}$ dominates in samples collected from hard rock aquifers. The WQI balanced with total dissolved solids and $\mathrm{Cl}$ observed high values representing the poor quality of groundwater for drinking purposes along the east and south parts of the study area dominated by domestic, agricultural, and industrial activities. Mixed $\mathrm{CaMgCl}>\mathrm{NaCl}$

Table 10 Classification of groundwater (Kelly 1957)

\begin{tabular}{lllllll}
\hline Range & Category & \multicolumn{2}{l}{ Hard rock terrain } & & \multicolumn{2}{l}{ Sedimentary terrain } \\
\cline { 3 - 4 } \cline { 6 - 7 } \cline { 6 - 7 } & & PRM & POM & & PRM & POM \\
\hline$<1$ & Suitable & $11(85 \%)$ & $10(77 \%)$ & $38(91 \%)$ & $38(91 \%)$ \\
1 to 2 & Marginal & $2(15 \%)$ & $3(23 \%)$ & $3(7 \%)$ & $4(9 \%)$ \\
$>2$ & Unsuitable & - & - & & $1(2 \%)$ & - \\
\hline
\end{tabular}

$>\mathrm{CaHCO}_{3}>\mathrm{CaCl}$ for hard rock samples and $\mathrm{NaCl}>$ Mixed $\mathrm{CaMgCl}>\mathrm{CaHCO}_{3}>\mathrm{CaCl}>$ mixed $\mathrm{CaNaHCO}_{3}$ in sedimentary samples dominate. Further, sodium adsorption ratio, $\mathrm{Na}$ $\%$, RSC, PI, and Kelly's ratio calculated in determining the irrigation suitability suggests about $85 \%$ of groundwater in the hard rock region and $70 \%$ of groundwater samples in the sedimentary region are useful for irrigation utilities. In loc no. 55 , higher sodium hazard and very high salinity are noted during PRM season indicating higher evaporation. The permeability index values suggest all the groundwater samples irrespective of the terrain and seasons are suitable for irrigation except loc no. 15 and 33 . The study of water quality parameters and its suitability for drinking and irrigation suggests the majority of the groundwater samples are apt except few samples flabby for irrigation purposes due to the high salinity. These areas with high salinity need adequate drainage to overcome salinity problems for irrigation purposes. The land use practice and the ion exchange course participate in a significant position in determining major geochemical processes of the study area.

\section{Declarations}

Conflict of interest The authors declare that they have no competing interests.

Open Access This article is licensed under a Creative Commons Attribution 4.0 International License, which permits use, sharing, adaptation, distribution and reproduction in any medium or format, as long as you give appropriate credit to the original author(s) and the source, provide a link to the Creative Commons licence, and indicate if changes were 
made. The images or other third party material in this article are included in the article's Creative Commons licence, unless indicated otherwise in a credit line to the material. If material is not included in the article's Creative Commons licence and your intended use is not permitted by statutory regulation or exceeds the permitted use, you will need to obtain permission directly from the copyright holder. To view a copy of this licence, visit http://creativecommons.org/licenses/by/4.0/.

\section{References}

Agrawal V, Jagetai M (1997) Hydrochemical assessment of groundwater quality in Udaipur city, Rajasthan, India. Proc. of National conference on dimensions of environmental stress in India. Department of Geology, MS University, Baroda, India, pp 151-154

Akakuru OC, Akudinobi B (2018) Determination of water quality index and irrigation suitability of groundwater sources in parts of coastal aquifers of Eastern Niger Delta Nigeria. Int J Appl Nat Sci 7:1-6

Alison EC, Janet SH, Blair FJ (1992) The chemical influence of clay minerals on groundwater composition in a lithologically heterogeneous carbonate aquifer. In: Kharaka YK, Maest AS (eds) Proceedings of the 7th international symposium on water-rock interaction (WRI7, Vol 2), Utah, Balkema, pp 779-782

American Public Health Association (APHA) (2012) Standard methods for the examination of water and waste water, 22nd edn. American Public Health Association, New York

Appelo CAJ, Postma D (2005) Geochemistry, groundwater and pollution, second edn. Taylor and Francis, Great Britain

Atikul Islam M, Zahid A, Rahman MM, Rahman MS, Islam MJ, Akter Y, Shammi M, Bodrud-Doza M, Roy B (2016) Investigation of groundwater quality and its suitability for drinking and agricultural use in the south central part of the coastal region in Bangladesh. Expo Health 9:27-41. https://doi.org/10.1007/s12403-016-0220-z

Bangar KS, Tiwari SC, Vermaandu SK, Khandkar UR (2008) Quality of groundwater used for irrigation in Ujjain district of Madhya Pradesh, India. J Environ Sci Eng 50(3):179-186

Bhardwaj V, Singh DS (2010) Surface and groundwater quality characterization of Deoria District, Ganga Plain. India. Environmental Earth Sciences 63:383-395. https://doi.org/10.1007/s12665-0100709-x

BIS (2003) Bureau of Indian Standards Specification for drinking water. IS: 10500:91. Revised 2003, Bureau of Indian Standards, New Delhi

Bodrud-Doza MD, Towfiqul Islam ARM, Ahmed F, Das S, Saha N, Safiur Rahma M (2016) Characterization of groundwater quality using water evaluation indices, multivariate statistics and geostatistics in central Bangladesh. Water Science 30:19-40. https://doi.org/10.1016/j.wsj.2016.05.001

Brindha K, Neena Vaman KV, Srinivasan K, Sathis Babu M, Elango L (2013) Identification of surface water-groundwater interaction by hydrogeochemical indicators and assessing its suitability for drinking and irrigational purposes in Chennai, Southern India. Appl Water Sci 4:159-174. https://doi.org/10.1007/s13201-013-0138-6

CGWB (2007) District Groundwater Brochure. Thrivuallur District, Tamil Nadu, India

Chen J, Wu H, HuiQian YG (2017) Assessing nitrate and fluoride contaminants in drinking water and their health risk of rural residents living in a semiarid region of northwest China. Expo Health 9:183195. https://doi.org/10.1007/s12403-016-0231-9

Chidambaram S, Ramanathan AL, Prasanna MV, Karmegam U, Dheivanayagi V, Ramesh R, Johnsonbabu G, Premchander B, Manikandan S (2010) Study on the hydrogeochemical characteristics in groundwater, post- and pre-tsunami scenario, from Portnova to Pumpuhar, southeast coast of India. Environ Monit Assess 169: 553-568. https://doi.org/10.1007/s10661-009-1196-y
Chidambaram S, Karmegam U, Prasanna MV, Sasidharm P, Vasanthavigar MA (2011) Study on hydrochemical elucidation of coastal groundwater in and around Kalpakkam region, southern India. Environ Earth Sci 64:1419-1431

Davis SN, DeWiest RJM (1966) Hydrogeology. Wiley, New York

Doneen LD (1964) Notes on water quality in agriculture, Published as a water sciences and engineering. Department of Water Sciences and Engineering, University of California, paper 4001

Durfer CM, Backer E (1964) Public water supplies of the three largest cities in the U.S. US Geological Survey water supply paper no.1812, 364

Durvey VS, Sharma LL, Saini VP, Sharma BK (1991) Handbook on the methodology of water quality assessment Rajasthan. Agriculture University, India

Eaton FM (1950) Significance of carbonate in irrigation waters. Soil Science 69:123-133

Freeze AR, Cherry JA (1979) Groundwater. Prentice-Hall Inc, Englewood cliffs 604

Frengstad B, Banks D, Siewers U (2001) The chemistry of Norwegian groundwater: IV. The $\mathrm{pH}$ dependence of element concentrations in crystalline bed rock groundwaters. Sci Total Environ 227:101-117

Ghandour EIM, Khalil JB, Atta SA (1985) Distribution of carbonates, bicarbonates and $\mathrm{pH}$ values in groundwater of the Nile delta region, Egypt. Groundwater 23:35-41

Giridharan L, Venugopal T, Jayaprakash M (2008) Evaluation of the seasonal variation on the geochemical parameters and quality assessment of the groundwater in the proximity of River Cooum, Chennai, India. Environ Monit Assess 143:161-178

Gopinath S, Srinivasamoorthy K (2015) Application of geophysical and hydrogeochemical tracers to investigate salinisation sources in nagapatinam and karaikal coastal aquifers, south India. Aquatic Proc 4:65-71

Gopinath S, Srinivasamoorthy K, Saravanan K, Suma CS, Prakash R, Senthilnathan D (2016) Modeling saline water intrusion in Nagapattinam coastal aquifers Tamilnadu, India. Model Earth Syst. Environ. 12. https://doi.org/10.1007/s408018-015-0058-6

Gopinath S, Srinivasamoorthy K, Saravanan K, Suma CS, Prakash R, Senthinathan D, Sarma VS (2017) Vertical electrical sounding for mapping saline water intrusion in coastal aquifers of Nagapattinam and Karaikal, South India. Sustain. Water Resour. Manag 4:833841. https://doi.org/10.1007/s40899-017-0178-4

Gopinath S, Srinivasamoorthy K, Saravanan K, Prakash R (2018) Discriminating groundwater salinization processes in coastal aquifers of southeastern India: geophysical, hydrogeochemicaland numerical modeling approach. Environ Dev Sustain 21:2443-2458. https://doi.org/10.1007/s10668-018-0143-x

Gopinath S, Srinivasamoorthy K, Saravanan K, Prakash R, Karunanidhi D (2019) Characterizing groundwater quality and seawater intrusion in coastal aquifers of Nagapattinam and Karaikal. South India using hydrogeochemistry and modeling techniques. Human and Ecological Risk Assessment: An International Journal 25:314 334. https://doi.org/10.1080/10807039.2019.1578947

GSI (2005) District resource map, Thiruvallur and Chennai district, Tamil Nadu, published by Geological Survey of India

Han D, Song X, Matthew JC (2016) Identification of anthropogenic and natural inputs of sulfate into a karstic coastal groundwater system in northeast China: evidence from major ions, d 13CDIC and d 34SSO4. Hydrol. Earth Syst. Sci. 20:1983e1999

$\mathrm{He} \mathrm{X}, \mathrm{Wu}$ J, He S (2018) Hydrochemical characteristics and quality evaluation of groundwater in terms of health risks in Luohe aquifer in Wuqi County of the Chinese Loess Plateau, northwest China. Hum Ecol Risk Assess 1:32-51. https://doi.org/10.1080/ 10807039.2018.1531693

Jain CK, Vaid U (2018) Assessment of groundwater quality for drinking and irrigation purposes using hydrochemical studies in Nalbari 
district of Assam, India. Environ Earth Sci 77:254. https://doi.org/ 10.1007/s12665-018-7422-6

Karnath KR (1989) Groundwater assessment, development and management. Tata McGraw Hill, New Delhi, p 720

Kelly WP (1957) Adsorbed sodium cation exchange capacity and percentage sodium sorption in alkali soils. Science 84:473-477

Khadse GK, Patni PM, Labhasetwar PK (2016) Water quality assessment of chenab river and its tributaries in Jammu Kashmir (India) based on WQI. Sustain Water Resour Manag. 2:121-126. https://doi.org/ 10.1007/s40899-016-0046-7

Krishna Kumar S, Hari Babu S, Eswar Rao P, Selvakumar S, Thivya C, Muralidharan S, Jeyabal G (2017) Evaluation of water quality and hydrogeochemistry of surface and groundwater, Thiruvallur District, Tamil Nadu, India. Appl Water Sci 7:2533-2544. https:// doi.org/10.1007/s13201-016-0447-7

Krishnakumar P, Lakshumanan C, Pradeep Kishore V, Sundararajan M, Santhiya G, Chidambaram S (2013) Assessment of groundwater quality in and around Vedaraniyam. South India, Environ Earth Sci 71:2211-2225. https://doi.org/10.1007/s12665-013-2626-2

Li P, He S, He X (2018a) Seasonal hydrochemical characterization and groundwater quality delineation based on matter element extension analysis in a paper wastewater irrigation area, northwest China. Expo Health. 10:241-258. https://doi.org/10.1007/s12403-170258-6

Li P, Wu J, Tian R (2018b) Geochemistry, hydraulic connectivity and quality appraisal of multilayered groundwater in the Hongdunzi Coal Mine, Northwest China. Mine Water Environ 37:222-237. https://doi.org/10.1007/s10230-017-0507-8

Lloyd JW, Heathcote JA (1985) Natural inorganic hydrochemistry in relation to groundwater. Clarendon Press, Oxford, An introduction

Mitra BK, Sasaki C, Keijirou E (2006) Spatial and temporal variation of ground water quality in sand dune area of Aomori prefecture in Japan, Paper number 062023, 2006 ASAE Annual Meeting. https://doi.org/10.13031/2013.20673

Mohan R, Singh AK, Tripathi J, Chowdhary GC (2000) Hydrochemistry and quality assessment of ground water in Naini industrial area, Allahabad District, Uttar Pradesh. J Geol Soc India 55:77-89

Mondal NC, Singh VP, Singh S, Singh VS (2011) Hydrochemical characteristic of coastal aquifer from Tuticorin, Tamil Nadu,India. Environ Monit Assess 175:531-550, Hydrochemical characteristic of coastal aquifer from Tuticorin, Tamil Nadu, India

Moquet J-S, Crave A, J er ${ }^{\wedge}$ omeViers S, Patrick A, Elisa B, Luc C, Eduardo L, Christelle L, Alain WSLC, Rodrigo P, Noriega L, Vera A, Guyot J-L (2011) Chemical weathering and atmospheric/ soil CO2 uptake in the Andean and Foreland Amazon basins. Chem Geol 287:1e26

Nagarajan R, Rajmohan N, Mahendran U, Senthamilkumar S (2010) Evaluation of groundwater quality and its suitability for drinking and agricultural use in Thanjavur City, Tamil Nadu, India. Environ Moni Asses 17:1289-1308. https://doi.org/10.1007/ s10661-009-1279-9

Naidu MS, Srinivas N, Rao VP (1998) Urban water quality in north coastal Andhra Pradesh. Indian J Environ Protect 18(4):273-277

Narsimha A (2018) Groundwater quality for drinking and irrigation purposes and potential health risks assessment: a case study from semiarid region of South India. Exposure and Health 11:109-123. https:// doi.org/10.1007/s12403-018-0288-8

Narsimha A, Sudarshan V (2017) Contamination of fluoride in groundwater and its effect on human health: a case study in hard rock aquifers of Siddipet, Telangana State, India. Appl Water Sci 7: $2501-2512$

Nazeer S, Hashmi MZ, Malik RN (2014) Heavy metals distribution, risk assessment and water quality characterization by Water quality index of the River Soan, Pakistan. EcolIndicat 43:262-270
Oinam JD, Ramanathan AL, Singh G (2012) Geochemical and statistical evaluation of groundwater in Imphal and Thoubal district of Manipur, India. Journal of Asian Earth Sciences 48:136-149

Parimala renganayaki S, Elango L (2013) Impact of recharge from a check dam on groundwater quality and assessment of suitability for drinking and irrigation purposes. Arab J Geosci. 7:3119-3129. https://doi.org/10.1007/s12517-013-0989-z

Piper AM (1944) A graphical procedure in the geochemicalinterpretation of water analysis. Transactions American Geophysical Union 25: 914-928

Prakash R, Srinivasamoorthy K, Gopinath S, Saravanan K (2018) Measurement of submarine groundwater discharge using diverse methods in Coleroon Estuary, Tamil Nadu, India. Applied Water Science 8:13. https://doi.org/10.1007/s13201-018-0659-0

Raghunath HM (1987) Groundwater, 2nd edn. New Age International Publications, New Delhi

Rajesh R, Brindha K, Murugan R, Elango L (2011) Influence of hydrogeochemical processes on temporal changes in groundwater quality in a part of Nalgonda district, Andhra Pradesh, India. Environ Earth Sci 65(4):1203-1213

Ramakrishnaiah CR, Sadashivaiah C, Ranganna G (2009) Assessment of water quality index for the groundwater in Tumkur taluk, Karnataka state, India. E-J Chem 6(2):523-530

Ramesh K, Elango L (2011) Groundwater quality and its suitability for domestic and agricultural use in Tondiar river basin. Tamil Nadu, India, Environ Monit Assess 184:3887-3899. https://doi.org/10. 1007/s10661-011-2231-3

Richards LA (1954) Diagnosis and improvement of saline alkaline soils, US Department of Agriculture. Hand Book 60(160)

Safei K, Arian M, Moien Zadeh Mirhosseini S (2015) Mineral chemistry and geothermometry of amphibole and plagioclase in the metabasites, located at the tambour metamorphic complex in southern iran. Open J Geol 5:795-808. https://doi.org/10.4236/ojg.2015. 511068

Saleh A, Al-Ruwaih F, Shehata M (1999) Hydrogeochemical processes operating within the main aquifers of Kuwait. Journal of Arid Environments 42:195-209

Sangodoyin AY, Ogedenbe K (1991) Surface water quality and quantity from the standpoint of irrigation and livestock. Int J Environ Stud 38:251-262

Saravanan K, Srinivasamoorthy K, Gopinath S, Prakash R (2016) Suma CS (2016) Investigation of hydrogeochemical processes and groundwater quality in Upper Vellar sub-basin Tamilnadu, India. Arab J Geosci 9:372. https://doi.org/10.1007/s12517-016-2369-y

Sawyer CN, McCarty DL (1967) Chemistry of sanitary engineers, 2nd edn. McGraw-Hill, New York, p 518

Senthilkumar S, Aruna M, Malathi D, Sivakumar R, Gowtham B (2014a) Hydrogeochemistry of Mailam block of TindivanamTaluk, Villupuram District, TamilNadu. Journal of Applied Geochemistry 16(1):64-80

Senthilkumar S, Balasubramanian N, Gowtham B, Lawrence JF (2014b) Geochemical signatures of groundwater in the coastal aquifers of Thiruvallur district, south India. Appl Water Sci 7:263-274. https://doi.org/10.1007/s13201-014-0242-2

Senthilkumar S, Gowtham B, Sundararajan M, Chidamparam S, Francis Lawrence J, Prasanna MV (2017) Impact of landuse on the groundwater quality along coastal aquifer of Thiruvallur district, South India. Sustain. Water Resour. Manag. DOI 4:849-873. https://doi. org/10.1007/s40899-017-0180-x

Senthilkumar S, Gowtham B, Vinodh K, Arulprakasam V, Sundararajan M (2017b) Delineation of geoelectic layers using imaging techniques in coastal blocks of Thiruvallur District, Tamil Nadu. Indian J Geo Mar Sci 46(05):986-994

Senthilkumar S, Vinodh K, Johnson Babu G, Gowtham B (2019) Arulprakasam V (2019) Integrated seawater intrusion study of 
coastal region of Thiruvallur district, Tamil Nadu. South India. Applied Water Science 9:124

Srinivasamoorthy K, Chidambaram M, Prasanna MV, Vasanthavigar M, John Peter A, Anandhan P (2008) Identification of major sources controlling groundwater chemistry from a hard rock terrain-a case study from Mettur taluk, Salem district, Tamil Nadu, India. J Earth Syst Sci 117(1):49-58

Srinivasamoorthy K, Nanthakumar C, Vasanthavigar M, Vijayaraghavan K, Rajivgandhi R, Chidambaram S, Anandhan P, Manivannan R, Vasudevan S (2011) Groundwater quality assessment from a hard rock terrain, Salem district of Tamilnadu, India. Arab J Geosci 4:91102. https://doi.org/10.1007/s12517-009-0076-7

Srinivasamoorthy K, Vijayaraghavan K, Vasanthavigar M, Sarma S, Chidambaram S, Anandhan P, Manivannan R (2012) Assessment of groundwater quality with special emphasis on fluoride contamination in crystalline bed rock aquifers of Mettur region, Tamilnadu, India. Arab J Geosci 5(1):83-94. https://doi.org/10.1007/s12517010-0162-x

Srinivasamoorthy K, Ponnumani G, Prakash R, Gopinath S, SaravananK VF (2018) Tracing groundwater inputs to Bay of Bengal from Sankarabarani River Basin. Pondicherry, India, using continuous radon monitoring, International Journal of Environmental Science and Technology 16:5513-5524. https://doi.org/10.1007/s13762018-1938-x

Subba Rao N (1993) Environmental impact of industrial effluents in groundwater regions of Visakhapatnam Industrial Complex. Indian Journal of Geology 65:35-43

Subramani T, Elango L, Damodarasamy SR (2005) Groundwater quality and suitability for drinking and agricultural use in Chithar river basin, Tamilnadu, India. Environ Geol 24(2005):194-202

Thivya C, Chidambaram S, Thilagavathi R, Prasanna MV, Singaraja C, Nepolian M (2013) Identification of the geochemical processes in groundwater by factor analysis in hard rock aquifers of Madurai District. South India. Arabian Journal of Geosciences 7:37673777. https://doi.org/10.1007/s12517-013-1065-4

Thorne DW, Peterson HB (1954) Irrigated Soils. In: Irrigated soils. Constable and Company, London

Todd DK (1980) Groundwater hydrology, 2nd edn. John Wiley and Sons, New York, p 535
USEPA (1999) National primary drinking water regulations, Available at http:/WWW.epa.gov/OGWD/hfacts.html

Vasanthavigar M, Srinivasamoorthy K, Vijayaragavan K, RajivGanthi R, Chidambaram S, Anandhan P, Manivannan R, Vasudevan S (2010) Application of water quality index for groundwater quality assessment: Thirumanimuttar sub-basin, Tamilnadu, India. Environ Moni Asses 171(2010):595-609. https://doi.org/10.1007/s10661-0091302-1

Vasanthavigar M, Srinivasamoorthy K, Rajiv Ganthi R, Vijayaraghavan K, Sarma VS (2012) Characterisation and quality assessment of groundwater with a special emphasis on irrigation utility: Thirumanimuttar sub-basin, Tamil Nadu, India. Arab J Geosci 5: 245-258. https://doi.org/10.1007/s12517-010-0190-6

Vengosh A, Gill J, Davisson ML, Hudson GB (2002) A multi-isotope (B, $\mathrm{Sr}, \mathrm{O}, \mathrm{H}$, and $\mathrm{C}$ ) and age dating (3 $\mathrm{He} 3 \mathrm{He}$ and $14 \mathrm{C})$ study of groundwater from Salinas Valley, California: hydrochemistry, dynamics, and contamination processes. Water Resour. Res. 38:1008

Venkatramanan S, Chung SY, Selvam S, Lee SY, Elzain HM (2017) Factors controlling groundwater quality in the Yeonjegu District of Busan City, Korea, using the hydrogeochemical processes and fuzzy GIS. Environ. Sci. Pollut. Res. 24:23679-23693

Vinnarasi F, Srinivasamoorthy K, Saravanan K, Gopinath S, Prakash R, Babu C, Ponnumani G (2020) Rare earth elements geochemistry of groundwater from Shanmuganadhi, Tamilnadu, India: chemical weathering implications using geochemical mass-balance calculations. Geochemistry 80:125668. https://doi.org/10.1016/j.chemer. 2020.125668

WHO (2004) Guidelines for drinking water quality, vol 1. Recommendations, 3rd edn. WHO, Geneva, p 515

WHO (2011) Water and sanitation. Guidelines for drinking-water quality

Wilcox LV (1955) Classification and use of irrigation waters. USDA, circular 969, Washington, DC, USA

Wu J, Xue C, Tian R (2017) Lake water quality assessment: a case study of Shahu Lake in the semi-arid loess area of northwest China. Environ Earth Sci 76:232. https://doi.org/10.1007/s126650176516-x

Yidana SM, Ophori D, Banoeng-Yakubo B (2010) Hydrogeological and hydrochemical characterization of the Voltaian Basin: The Afram Plains area, Ghana. Environmental Geology 53(2010):1213-1223 